\title{
GLOBALIZAÇÃO E MUDANÇAS NA CONFIGURAÇÃO ESPACIAL: DA ECONOMIA MUNDIAL UMA VISÃO PANORÂMICA DAS ÚLTIMAS DÉCADAS*
}

\section{Olimpio J. de Arroxelas Galvãa ${ }^{* *}$}

RESUMO Este artigo faz um exame dos macrocenários mundiais nas últimas décadas, apontando os principais problemas atuais, os riscos, desafios e oportunidades com que se defrontará o mundo ao longo dos próximos anos. O trabalho mostra que nas últimas décadas aumentou significativamente a distância entre os países ricos e pobres, mas o desempenho da economia mundial, do ponto de vista geográfico, ocorreu de forma extremamente desigual. Enquanto o Sul e o Leste da Ásia apresentaram desempenho extraordinariamente dinâmico, a maioria das demais regiões do mundo em desenvolvimento, e de modo particular a África Subsaariana, os países ex-comunistas da Europa e a América latina exibiram taxas medíocres ou mesmo negativas de crescimento de seus PIBs per capita. Com esse padrão de evolução, a economia mundial estaria passando por grandes mudanças na configuração espacial da produção, alterando o equilíbrio das forças econômicas globais e criando uma nova geografia do poder. Um contraponto com o Brasil é apresentado ao final do artigo.

Palavras-chave: globalização e macrocenários mundiais; Brasil, China e Índia; mudanças na geografia econômica mundial

Código JEL: FO1

* Artigo recebido em 14 de março de 2006 e aprovado em 2 de fevereiro de 2007.

** Ph.D. em Economia pela Universidade de Londres e Mestre em Economia pela Universidade de Yale, professor aposentado da UFPE, professor titular em tempo integral do Curso de Mestrado em Gestão Empresarial e do Departamento de Economia da Faculdade Boa Viagem, no Recife, e pesquisador bolsista nível I do CNPq, e-mail: olimpio.galvao@uol.com.br e olimpio.galvao@pesquisador. cnpq.br 


\section{GLOBALIZATION AND CHANGES IN THE SPATIAL CONFIGURATION OF THE WORLD ECONOMY: AN OVERVIEW OF THE LAST DECADES}

ABSTRACT This paper analyses some world macro scenarios in the last decades, pointing out the most recent trends, the risks, the challenges and opportunities which the world as a whole faces in the next years. The work shows that in the last decades the distance between the rich and the poor countries increased dramatically, but that the performance of the world economy exhibited an extremely unequal behavior, from the geographic perspective. Whereas the South and the East Asia regions presented extraordinary dynamic performance, most of the other developing areas, and very particularly Subsahara Africa, the ex-communist European countries and Latin America, experimented mediocre growth rates. With such recent patterns the world economy would be going through big changes in the spatial configuration of its production, altering the equilibrium of the global economic forces and creating a new geography of power. In the end of the work a counterpoint is made as far as Brazil is concerned.

Key words: globalization and world macro scenarios; Brazil, China and India; changes in the world economic geography 


\section{INTRODUÇÃO}

Este estudo faz um exame da evolução recente da economia mundial e das projeções de crescimento esperado para os próximos 10 anos, e aponta os principais problemas atuais, os riscos, desafios e oportunidades com que se defrontará o mundo ao longo do período mencionado. Dentro desse panorama geral da evolução da economia internacional, serão destacados regiões, países e grupos de países os quais, pela sua importância na ordem mundial, ou decorrentes de peculiaridades especiais, merecem um comentário à parte.

Três grandes tópicos merecerão destaque especial. Na seção 1, é traçado um breve perfil do crescimento da economia mundial, contemplando o seu desempenho em passado recente, assinalando as tendências atuais e fazendo projeções de evolução para a próxima década ou um pouco mais, calcadas em estudos de respeitadas organizações internacionais. A seguir, na seção 2, são feitas considerações sobre a continuidade dos processos de globalização, em suas várias dimensões, principalmente a comercial, a financeira e a tecnológica, examinando-se o surgimento de novas tendências de mudança na configuração espacial da economia mundial. A seção 3 discute os casos especiais de crescimento de dois países - a China e a Índia —, os quais, pela sua expressão demográfica e dimensão continental, estão sendo considerados como capazes de mudar o equilíbrio e o foco da economia mundial, em futuro não muito distante. Uma última seção apresenta as conclusões. Vale ressaltar que a apreciação dos temas mencionados será realizada na perspectiva de que está sendo criada uma nova arquitetura institucional, em âmbito mundial, que exercerá profunda influência sobre a trajetória futura das economias da América Latina e, particularmente, do Brasil.

\section{O CRESCIMENTO DA ECONOMIA MUNDIAL: O PASSADO RECENTE, AS TENDÊnCIAS ATUAIS E PROJEÇÕES PARA O FUTURO}

Nas últimas pouco mais de três décadas a economia mundial apresentou um desempenho bastante volátil, entremeado por altas, médias e baixíssimas taxas de crescimento do PIB agregado total e per capita de todas as nações. 
Nesse período, cuja série se inicia em 1970 e vai até 2004, o mundo foi acometido por grandes crises econômicas — algumas com impactos globais, como a brusca elevação dos preços do petróleo e das taxas de juros nos mercados financeiros internacionais - e por diversas outras com efeitos mais localizados, mas que também influenciaram negativamente o desempenho de vastas regiões do mundo, afetando a dinâmica regional de crescimento, através do que se poderia denominar "efeito dominó". ${ }^{1} \mathrm{O}$ panorama do mundo aqui brevemente resenhado corresponde a um período que sucedeu a dois outros anteriores, que receberam muito adequadamente as denominações de "Era da Catástrofe" (que durou de 1914 a 1945) e "Era Dourada” (com duração entre os anos do pós-guerra e o início da década de 1970), conforme a periodização histórica do clássico estudo de Eric Hobsbawn (Hobsbawn, 1995). Ainda segundo Hobsbawn, as décadas que se seguiram — de 1970 aos dias atuais — caracterizariam uma nova era de "decomposição, incertezas e crise" (idem: 6) e talvez a uma outra quase Era da Catástrofe, como também sugerido pelo autor citado, em virtude de alguns importantes e dramáticos acontecimentos: as inúmeras guerras civis em diversos países africanos, levando à morte, à invalidez e ao empobrecimento de dezenas de milhões de pessoas; a longa crise econômica, iniciada na entrada dos anos 1970, responsável por cerca de duas décadas perdidas de crescimento em grande parte do mundo em desenvolvimento; as guerras de limpeza étnica, no limiar do século XX, promovidas pelos sérvios nas várias nações que constituíam a antiga Iugoslávia; e os anos da penosa transição das nações da antiga União Soviética e dos países do Leste e do Centro europeus, do regime comunista para o de economias de mercado.

O conjunto dos seis gráficos adiante, com informações referentes às últimas três décadas e meia, registra, sob diversos ângulos e dimensões, a conturbada evolução da economia mundial, em seu agregado. Os destaques a seguir merecem especial atenção:

(i) Embora apresentando uma tendência crescente de longo prazo, foi bastante oscilante o comportamento das taxas médias anuais de crescimento da economia mundial, com valores variando entre $1 \% \mathrm{e}$ quase 7\% (gráfico 1). Esses dados, por revelarem apenas o desempenho da economia mundial como um todo, deixam implícita a enorme margem de oscilação do crescimento entre as grandes regiões do 
mundo e os países isoladamente, como será verificado quando da desagregação geográfica dessas informações, mais adiante.

(ii) Na perspectiva do crescimento do PIB per capita mundial, as informações disponíveis também revelam uma tendência de evolução positiva nas últimas três décadas e meia (gráfico 2). As oscilações dessas taxas, ano a ano, contudo, registram uma muito mais acentuada volatilidade dos PIBs per capita, com variações entre cerca de 5\% de crescimento positivo a valores muito perto de zero e até negativos. Esses dados expressam, como será mostrado adiante, que, a despeito dos avanços na média da renda per capita do mundo como um todo, a distribuição dos frutos do desenvolvimento econômico ocorreu de forma muito desigual, do ponto de vista geográfico, com países registrando notáveis progressos nas áreas econômica e social, ao lado de outros que revelaram pequenos ganhos ou, em muitos casos, até mesmo perdas líquidas de rendimento e de bem-estar, durante grande parte do período aqui observado.

(iii) As últimas décadas registraram uma extraordinária expansão do comércio internacional de bens e serviços (gráfico 3), resultado do aprofundamento dos processos de globalização e propiciando expressivo aumento na interdependência econômica das nações de todo o mundo. Essa expansão, todavia, também ocorreu de forma extremamente desigual entre as grandes regiões e países dos vários continentes. Como o comércio internacional é visto, cada vez mais, como um poderoso mecanismo de elevação da produtividade dos recursos produtivos, de promoção do crescimento econômico e de avanço na esfera social, diferenças significativas nos níveis de inserção das economias nacionais nos fluxos mundiais de bens, de serviços e de tecnologia estão constituindo também uma fonte de enormes disparidades internacionais de crescimento econômico e de níveis de bem-estar.

(iv) Os últimos três gráficos seguintes revelam outras características relevantes do desenvolvimento da economia mundial. O gráfico 4 mostra a ocorrência de substanciais desequilíbrios internos, gerados por expressivas oscilações nas taxas mundiais de inflação. Mas revela, também, um progressivo declínio nessas taxas, nos países indus- 
trializados, a partir da segunda metade da década de 1980, e o mesmo fenômeno nos países em desenvolvimento, a partir da segunda metade da década seguinte e, refletindo esforços crescentes dos governos nacionais voltados para o controle inflacionário, sobretudo por meio da adoção de rígidas medidas de políticas nas áreas fiscal e monetária.

(v) O gráfico 5 apresenta um fato de extrema relevância: à exceção de poucos anos da primeira metade da década de 1980 (resultado da turbulência provocada pela drástica elevação dos preços do petróleo), a taxa real de juros de longo prazo tem-se mantido baixa na maioria dos países (e às vezes negativa, em muitos), e apresenta tendência firme de declínio a partir da segunda metade da década de 1980, alcançando, na década de 1990 e nos primeiros anos de 2000, patamares da ordem de 3\% ou menos. Essa tendência sinaliza que reduzidas taxas de juros são as práticas dominantes nos mercados, sugerindo que deve constituir firme objetivo de cada governo nacional mantê-las baixas, em virtude da forte associação entre crescimento econômico de longo prazo e o nível dessas taxas.

(vi) O gráfico 6 do conjunto aqui apresentado mostra a evolução dos preços reais das commodities em um longo período de mais de 30 anos. As informações constantes nesse gráfico apontam para dois fatos muito relevantes. O primeiro é o da forte oscilação dos preços do petróleo e da tendência crescente desses preços nos anos recentes, sugerindo os riscos a que estão permanentemente submetidos os países dependentes de importações dessa commodity. O segundo fato, ainda mais importante, é o da tendência de longo prazo dos preços das outras commodities que não o petróleo. A despeito de tais preços revelarem uma oscilação bem menor do que o petróleo, pela razão óbvia de que o gráfico mede o comportamento médio de um grande número de produtos e não apenas o de uma única commodity, a linha de tendência de longo prazo dos preços de todas as outras commodities revela claramente uma firme e inquestionável direção: o declínio sistemático, quase linear, dos preços dos produtos primários comercializados no mercado internacional. Essa tendência conduz, sem dúvida, para os seguintes alertas: o de que os países devem 
INDICADORES GLOBAIS E PROJEÇÕES DE CRESCIMENTO: 1970-2010
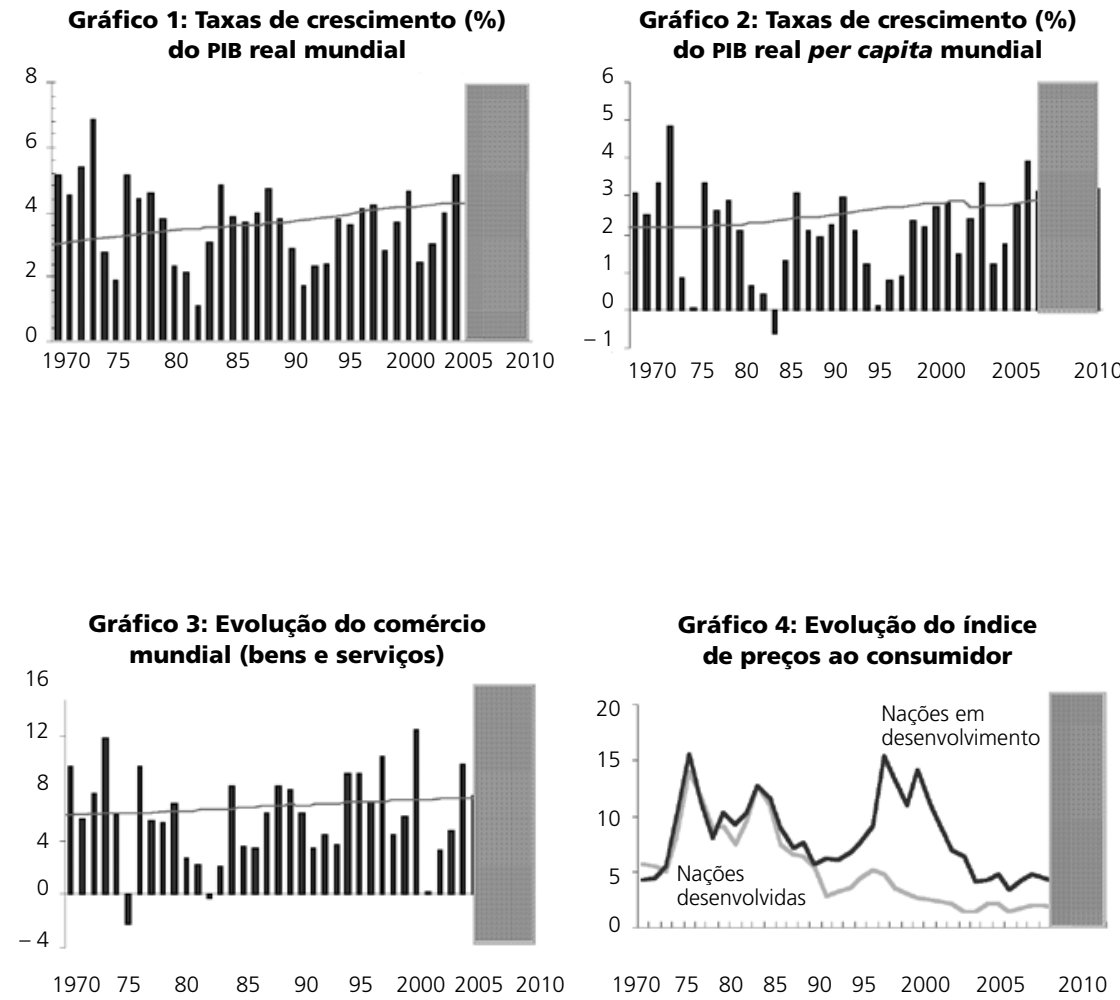
Gráfico 4: Evolução do índice de preços ao consumidor
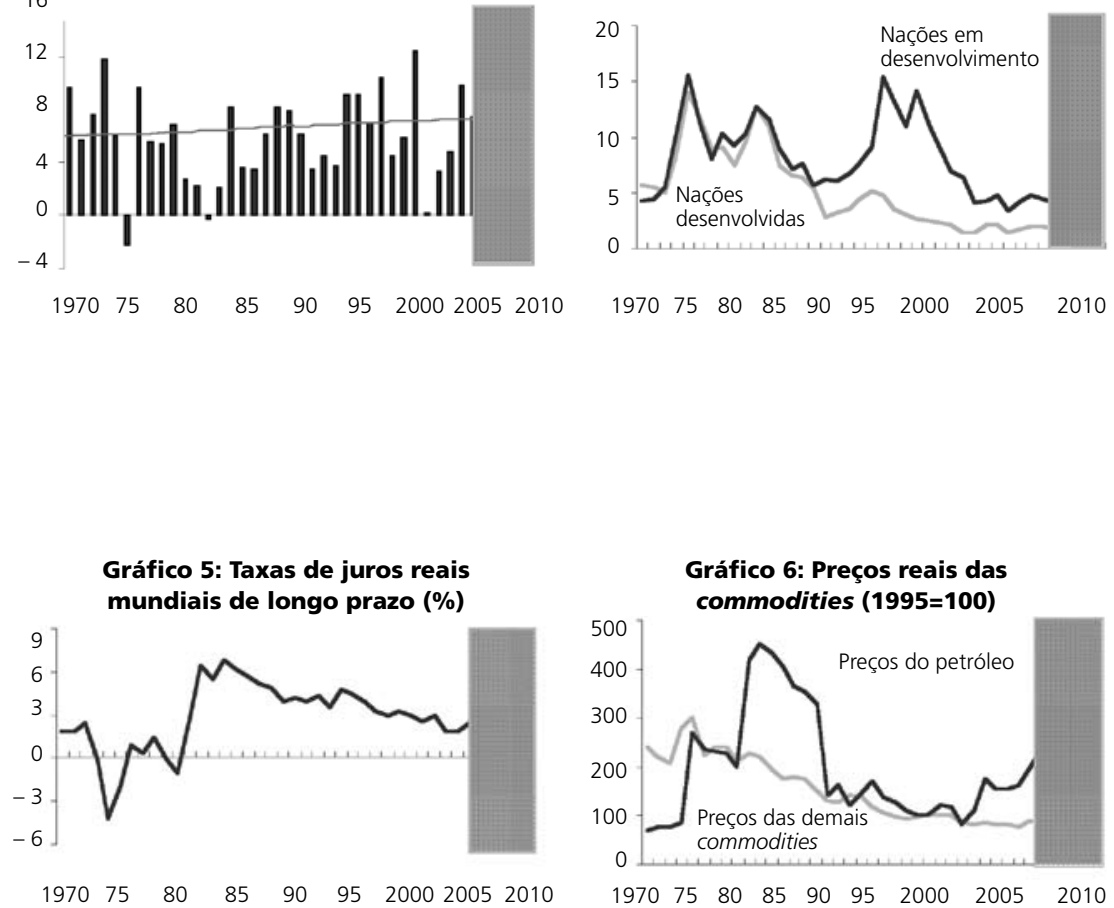

Fonte (incluindo metodologia de coleta e computação dos dados): World Economic Outlook, IMF (2005). A área hachurada corresponde à projeção do FMI para o período 2005-2010. 
diversificar a pauta das exportações de bens primários, de modo a contrabalançar os efeitos cíclicos das variações de curto prazo de seus preços; o de que cada país deve procurar agregar valor às suas principais commodities, para se contrapor à tendência de declínio de seus preços no mercado; e o de que os países exportadores de primários devem adotar políticas no médio e longo prazos, voltadas para a redução relativa da importância de bens primários da sua pauta exportadora, e aumentar a participação de produtos manufaturados. $^{2}$

O conjunto dos gráficos apresentadas ainda revela outros aspectos importantes do desempenho da economia mundial.

O Relatório do Fundo Monetário Internacional do ano de 2005 (de onde foram extraídas as informações até aqui analisadas) e os de outros organismos internacionais para o mesmo ano, como os do Banco Mundial, da Organização Mundial para o Comércio e das Nações Unidas, mostram que a economia mundial vem apresentando um excelente desempenho nos anos mais recentes — havendo crescido 4\% em 2003 e 5,1\% em 2004 -, registrando-se neste último ano, inclusive, a maior taxa de crescimento do PIB mundial das duas últimas décadas (gráfico 1 ). ${ }^{3}$

O FMI faz estimativas para os anos 2005 e 2006 e projeta o crescimento da economia mundial até 2010 (ver o conjunto dos gráficos apresentados, principalmente o gráfico 1). Em ambos os casos, as estimativas do Fundo são otimistas. O FMI destaca, porém, que haverá uma pequena desaceleração do crescimento mundial em 2005 e em 2006, em parte como reflexo do próprio retorno a uma situação de crescimento mais normal, ou sustentável, e em parte por causa do aumento dos preços do petróleo.

Para o restante da década, as previsões são de um crescimento robusto, da ordem de $3 \%$, ou pouco mais, ao ano, taxas consideradas muito satisfatórias, sobretudo se levando em conta o fraco desempenho da economia mundial nas últimas duas décadas.

O otimismo do FMI (bem como também dos estudos das outras organizações citadas) baseia-se em alguns fatos observados: o de que o mundo tem presenciado uma grande parte de países praticando políticas macroeconômicas "corretas" (ou seja, obedecendo ao receituário das organizações internacionais no que diz respeito aos "fundamentos" da economia); o de que a 
inflação tem sido mantida sob controle em crescente número de países; o de que o mercado financeiro tem tido um comportamento "benigno" (na expressão do próprio Fundo), sem dar grandes sustos na comunidade internacional; e o de que o comércio internacional deverá continuar se expandindo a taxas elevadas (em parte devido à continuidade dos processos de liberalização comercial), contribuindo, assim, para manter promissor o ambiente de crescimento do PIB mundial (FMI, 2005; Banco Mundial, 2005a e 2005b; e OMC/WTO, 2005).

O FMI chega até a arriscar uma projeção para um período mais longo do que 10 anos, embora deixe claro que predições sobre crescimento econômico futuro de longo prazo apresentam grandes margens de erro e incertezas. Mesmo assim, o Fundo faz uma projeção de crescimento para a economia mundial de 3,6\% ao ano, para o longo período de 2003 a 2030 (ver p. 179 de seu "Outlook" de 2005), embora levante de modo enfático uma série de ressalvas e preocupações: a de que o crescimento global tem-se tornado mais desequilibrado do ponto de vista geográfico (uma questão à qual se retornará mais adiante), com disparidades crescentes entre algumas regiões e países; a de que esse crescimento tem dependido significativamente do desempenho das economias dos Estados Unidos e da China, nos anos mais recentes; a de que tem sido decepcionante o crescimento da Europa (sobretudo o da zona do Euro) e do Japão na última década; a de que o agravamento da posição externa da economia dos Estados Unidos pode promover impactos futuros negativos sobre a taxa de juros e o mercado financeiro internacional, em prejuízo das economias dos países em desenvolvimento; e a de que a continuidade da tendência atual de manutenção ou mesmo elevação dos preços do petróleo pode alterar para baixo todas as projeções otimistas sobre o crescimento da economia mundial para os próximos anos. ${ }^{4}$

Examinando-se, agora, o desempenho da economia mundial em uma perspectiva geográfica, o fato mais importante a destacar é o de que o crescimento ocorreu, nas últimas décadas, de forma extremamente desigual.

Fortes assimetrias de crescimento dominaram os cenários mundiais, com continentes, grandes regiões e países registrando desempenhos bastante díspares - alguns com performance excepcional, muitos com comportamento próximo do medíocre e outros até mesmo exibindo taxas negativas de expansão de seus PIBs per capita, por longos períodos de tempo. 
Nas duas décadas passadas (a dos anos 1980 e 1990), aumentou significativamente a distância entre os países ricos e pobres. A tabela 1, que contém dados apresentados pelo Banco Mundial, mostra que, enquanto os países desenvolvidos registraram crescimento real de suas rendas per capita de 2,5\% ao ano, na década de 1980, e de 1,8\%, na de 1990, o conjunto dos países em desenvolvimento exibiu um crescimento de tão-somente $0,6 \%$ e $1,5 \%$, nas duas décadas mencionadas. Vale notar, todavia, que o distanciamento entre os países ricos e pobres reflete apenas uma média do comportamento do total dos dois grandes conjuntos de países, já que a observação do crescimento por regiões mostra um desempenho extraordinariamente dinâmico das nações do Leste e do Sul asiáticos, ao lado do fracasso total das demais regiões do mundo em desenvolvimento (e de modo muito particular da África Subsaariana e da América Latina) em acompanhar sequer o ritmo de expansão das economias mais maduras e industrializadas, que costumam apresentar menores taxas de crescimento de longo prazo.

As informações da tabela 1 destacam, de modo especial, o impressionante dinamismo dos países em desenvolvimento do Leste da Ásia. Essa região, embora muito heterogênea e ainda abrigando alguns dos países mais pobres do mundo, registrou taxas de crescimento per capita maiores que o dobro da média de todos os países industrializados, na década de 1980 (5,8\% contra 2,5\%), e mais do que o triplo dessas taxas na década de 1990 (6,3\% contra 1,8\%). Nessa região, o crescimento foi puxado pelos quatro "tigres" da Ásia (Coréia do Sul, Taiwan, Cingapura e Hong Kong) e a nova geração de países exportadores (Tailândia, Malásia, Filipinas, Indonésia, entre outros), mas principalmente pela China — país que tem registrado vibrante e ininterrupto desempenho desde a adoção de seu programa de reforma econômica em dezembro de 1978.

O Sul da Ásia foi outra região a apresentar bom desempenho nas duas últimas décadas. Compreendendo um conjunto de nações muito pobres e populosas do continente asiático (Bangladesh, Paquistão, Sri-Lanka e Índia, entre outros), o crescimento dessa região pode também ser considerado bastante expressivo, registrando expansão de seu PIB real per capita anual a taxas de 3,3\%, na década de 1980 , e de 3,2\%, na de 1990 . Nessa região, o crescimento foi puxado pelo seu país mais populoso, a Índia, com popula- 
Tabela 1: Crescimento de longo prazo do PIB real per capita (baseado em médias anuais)

\begin{tabular}{lcc}
\hline Discriminação & $1980 / 1989$ & $1990 / 1999$ \\
\hline Total Mundial & 1,3 & 1,1 \\
\hline Países de Alta Renda & 2,5 & 1,8 \\
\hline OCDE & 2,5 & 1,7 \\
\hline Estados Unidos & 2,2 & 1,9 \\
\hline Japão & 3,5 & 1,1 \\
\hline União Européia & 2,1 & 1,8 \\
\hline Paises Fora da OCDE & 3,5 & 4,1 \\
\hline Países em Desenvolvimento & 0,6 & 1,5 \\
\hline Leste da Ásia e o Pacífico & 5,8 & 6,3 \\
\hline Leste Europeu e Ásia Central & 1,0 & $-1,8$ \\
\hline América Latina e Caribe & $-0,9$ & 1,5 \\
\hline Oriente Médio e Norte da África & $-1,6$ & 1,1 \\
\hline Sul da Ásia & 3,3 & 3,2 \\
\hline África Sub-Sahariana & $-1,2$ & $-0,5$ \\
\hline Fonte: WORLD BANK. Global Economic Prospects 2005: trade, regionalism and development. Washington: The World Bank, \\
2005a. \\
$\begin{array}{l}\text { Nota: Agregações correspondem a médias móveis, reponderadas anualmente após o cálculo do crescimento [do PIB real per } \\
\text { capita] em preços constantes }\end{array}$
\end{tabular}

ção de quase 1 bilhão de habitantes, e que apresentou, no período aqui analisado, também um impressionante desempenho.

Em claro e indiscutível contraste com as duas regiões asiáticas, a África Subsaariana e a América Latina (nos dados do Banco Mundial incluindo o Caribe) registraram comportamento extremamente insatisfatório. As nações africanas abaixo do Saara - as que tiveram, de todas as regiões, a pior performance - experimentaram um crescimento negativo de seus PIBs per capita em toda a longa série de 20 anos aqui considerada: 1,2\% de decréscimo anual na década de 1980 e 0,5\% na de 1990. Essa parte do continente africano, portanto, vivenciou claramente duas décadas perdidas de crescimento, em virtude de uma grande variedade de fatores, mas principalmente em decorrência da crise do petróleo, que acarretou forte endividamento externo e redução de sua capacidade de importação, sobretudo de alimentos, nas duas décadas mencionadas, e também em decorrência das inúmeras guerras civis por que passaram esses países ao longo da segunda metade do século XX. ${ }^{5}$ A região da América Latina e do Caribe, como um todo, tam- 
bém teve a sua década perdida nos anos 1980 - atestada pelo crescimento negativo de seu PIB per capita, de - $0,9 \%$ ao ano - , apresentando um medíocre crescimento de $1,5 \%$ na década seguinte, pouco mais que compensando as enormes perdas sofridas por essa região na década anterior. O mau desempenho de suas três principais economias - o Brasil, o México e a Argentina -, vitimadas por recorrentes crises externas e internas ao longo das duas décadas, é responsável, em larga medida, pelo fracasso dos países centro e sul-americanos em termos de crescimento e de elevação de seus níveis de bem-estar. No que diz respeito ainda a essas duas regiões, é importante assinalar a observação que faz um outro estudo recente do Banco Mundial: a de que a África Subsaariana e a América Latina são as regiões que apresentam as mais profundas desigualdades sociais de todo o mundo (World Bank, 2005b).

As duas outras grandes regiões, constantes da tabela 1, que compreendem o restante dos países em desenvolvimento - o Oriente Médio e Norte da África e a Europa Central e parte da Ásia européia —, também exibiram sérios problemas para crescer, nas duas décadas passadas. As nações do Oriente Médio e do Norte da África apresentaram desempenho ainda inferior ao da América Latina, tanto na década de 1980 quanto na de 1990, vitimadas por severos conflitos internos, instabilidade política e forte declínio dos preços do petróleo, a partir da segunda metade dos anos 1980. Quanto à região denominada pelo Banco Mundial "Europa e Ásia Central” — constituída pelas economias sob regime comunista até o final da década de 1980 e início da de 1990 —, ela apresentou um desempenho medíocre nos anos 1980 (um crescimento de apenas $1 \%$ ao ano do PIB per capita) e um decréscimo da ordem de 1,8\% ao ano, desse indicador de crescimento, na década seguinte. Na primeira das duas décadas aqui consideradas, o resultado alcançado por esses países refletiu a profunda crise política e econômica por que passou o regime socialista europeu e da qual resultou, na década seguinte, no total desmantelamento desse regime - responsável pelo crescimento negativo apresentado na década de 1990 pela região, em decorrência dos severos problemas enfrentados por seus países durante os penosos anos de transição de economias de comando para economias democráticas e de mercado. 


\section{A CONTINUIDADE DA GLOBALIZAÇÃO E AS NOVAS TRAJETÓRIAS DE MUDANÇAS NA CONFIGURAÇÃO DA ECONOMIA MUNDIAL}

As últimas quatro décadas registraram profundas transformações na natureza das articulações internacionais em vários níveis: no ritmo do crescimento do comércio de bens e serviços, na aceleração no movimento dos fluxos dos ativos financeiros, na rapidez com que novas tecnologias são criadas e transferidas internacionalmente, no desenvolvimento de novos e mais velozes sistemas de comunicações (transportes, telecomunicações, Internet etc.), na transferência e absorção do conhecimento e da informação.

Todas essas transformações trouxeram implicações extremamente importantes: elas moveram os países em direção a uma economia mundial cada vez mais sem fronteiras, tornando as economias nacionais altamente interdependentes e fazendo os movimentos internacionais de bens, de serviços, de tecnologia, de informações e de conhecimentos muito mais importantes nos dias atuais do que em qualquer outra época da humanidade.

Considerando apenas o comércio de bens tangíveis, dados da Organização Mundial do Comércio - OMC - mostram que o comércio internacional de mercadorias registrou impressionante ritmo de crescimento desde o final da Segunda Guerra Mundial: os fluxos de mercadorias se expandiram, entre 1950 e 2000, a uma taxa média de mais de 6\%, em termos reais, multiplicando o volume das transações internacionais em cerca de 15 vezes e fazendo com que a fração da produção mundial exportada de mercadorias passasse de 7\%, em 1950, para cerca de 25\%, em 2000. A tabela 2 mostra a evolução do comércio mundial para o período 1960-2000.

Embora a maior parcela desses fluxos seja ainda realizada entre os próprios países industrializados, o comércio das nações menos desenvolvidas tem crescido a taxas muito mais elevadas (cerca de $10 \%$ ao ano, entre 1980

Tabela 2: Crescimento do comércio exterior de mercadorias, 1960-2000

(Exportações em US\$ correntes - cifras arredondadas)

\begin{tabular}{cc}
\hline Anos & Volume de comércio \\
\hline 1960 & 130 bilhões \\
\hline 1985 & 2 trilhões \\
\hline 1995 & 6 trilhões \\
\hline 2000 & 9 trilhões \\
\hline
\end{tabular}

Fonte: OMCMTO, World Trade Reports, vários relatórios anuais. 
e 2000), especialmente entre os NICs e os NECs — ou seja, os países considerados recém-industrializados (os Newly Industrialized Countries, entre os quais se destacam os quatro "tigres asiáticos" e países como o Brasil, o México, a Argentina e a Índia) e as nações chamadas de recém-exportadoras (os Newly Exporting Countries, entre os quais se incluem a China, a Tailândia, a Malásia, as Filipinas, a Indonésia, o Chile e até o Vietnã). ${ }^{6}$

Mais importante ainda são os fluxos internacionais de serviços e de capitais. Em 2003, o estoque de capitais estrangeiros (investimentos diretos e de portfolio) investidos em todo o mundo equivalia a quase US\$ 40 trilhões norte-americanos, a grande maioria realizados pelos Estados Unidos, pelos europeus e japoneses - uma cifra que mal ultrapassava os dois trilhões em 1980 (FMI, 2005: 112; e tabela 3 deste trabalho). Na Ásia, na América Latina e em várias outras áreas do mundo, a presença da empresa estrangeira - européia, norte-americana ou japonesa — é enorme e crescente. Na esfera da globalização industrial, o papel da empresa transnacional tem chamado a atenção dos analistas e das organizações internacionais. Segundo dados da OMC e do FMI, cerca de 70\% do comércio mundial eram realizados por empresas multinacionais, e mais de metade dessa cifra representava transações realizadas apenas entre suas próprias afiliadas - o chamado comércio intrafirma (FMI, 2005; e OMC/WTO, 2005). Para concluir o quadro, e refletindo o avanço extraordinário da interdependência das economias nacionais, merecem destaque especial os movimentos internacionais do capital financeiro, através de bolsas de valores e mercadorias, das vendas de papéis e títulos públicos e de outros mecanismos ligados à órbita do capital de curto prazo, comumente denominado especulativo. Com a expansão de antigos mecanismos de transferência internacional de riquezas e o surgimento de uma série de outros novos, introduzidos em décadas recentes, estima-se na casa das dezenas de trilhões de dólares os movimentos de recursos que operam no mercado de derivativos (operações a termo, a futuro e swaps, além de operações cambiais não comerciais), em grande parte decorrentes da aplicação dos saldos das contas correntes de países exportadores, das poupanças de grandes investidores institucionais (fundos de pensão, fundos mútuos e de seguradoras) e das carteiras que gerenciam as grandes fortunas pessoais.

Com base em toda essa imensa massa de riqueza mobiliária líquida, também se estima que o equivalente a mais de uma dezena de trilhões de dólares 
Tabela 3: Contabilidade de Ativos e Passivos mundiais brutos, 1980-2003 Em US\$ bilhões (exclusive os ativos externos mantidos pelos bancos centrais)

\begin{tabular}{|c|c|c|c|c|c|c|}
\hline Discriminação & 1980 & 1985 & 1990 & 1995 & 2000 & 2003 \\
\hline \multicolumn{7}{|l|}{ Ativos externos } \\
\hline Países industrializados & 2.287 & 3.975 & 9.701 & 15.334 & 26.810 & 36.039 \\
\hline América do Norte & 668 & 1.310 & 2.331 & 4.107 & 7.914 & 8.454 \\
\hline Estados Unidos & 584 & 1.185 & 2.119 & 3.754 & 7.265 & 7.680 \\
\hline Europa & 1.474 & 2.232 & 5.522 & 8.659 & 16.066 & 24.311 \\
\hline França & 203 & 265 & 722 & 1.292 & 2.323 & 3.317 \\
\hline Alemanha & 216 & 308 & 1.017 & 1.579 & 2.504 & 3.867 \\
\hline Reino Unido & 519 & 838 & 1.695 & 2.342 & 4.400 & 6.293 \\
\hline Ásia e Pacífico & 145 & 433 & 1.848 & 2.568 & 2.830 & 3.273 \\
\hline Japão & 134 & 410 & 1.778 & 2.445 & 2.605 & 2.922 \\
\hline $\begin{array}{l}\text { Mercados emergentes } \\
\text { e outros países em } \\
\text { desenvolvimento }\end{array}$ & 114 & 193 & 366 & 711 & 1.479 & 1.849 \\
\hline Ásia & 28 & 72 & 166 & 384 & 948 & 1.193 \\
\hline China & 一 & 18 & 25 & 47 & 225 & 273 \\
\hline Coréia do Sul & 4 & 7 & 17 & 58 & 103 & 127 \\
\hline Malásia & 4 & 7 & 5 & 13 & 39 & 53 \\
\hline Tailândia & 1 & 2 & 7 & 4 & 2 & 23 \\
\hline América Latina & 55 & 80 & 126 & 214 & 325 & 386 \\
\hline Argentina & 4 & 5 & 6 & 3 & 3 & 2 \\
\hline Brasil & 10 & 19 & 29 & 51 & 74 & 96 \\
\hline México & 9 & 21 & 37 & 50 & 45 & 30 \\
\hline Outros & 31 & 42 & 74 & 113 & 206 & 270 \\
\hline \multicolumn{7}{|l|}{ Passivos Externos } \\
\hline Países industrializados & 2.485 & 4.186 & 10.531 & 16.139 & 28.419 & 39.039 \\
\hline América do Norte & 708 & 1.464 & 2.909 & 4.849 & 9.741 & 11.452 \\
\hline Estados Unidos & 525 & 1.206 & 2.459 & 4.274 & 8.965 & 10.476 \\
\hline Europa & 1.578 & 2.311 & 5.835 & 9.096 & 16.386 & 24.790 \\
\hline França & 193 & 306 & 845 & 1.385 & 2.214 & 3.247 \\
\hline Alemanha & 224 & 289 & 751 & 1.535 & 2.534 & 3.794 \\
\hline Reino Unido & 508 & 755 & 1.762 & 2.426 & 4.497 & 6.429 \\
\hline Ásia e Pacífico & 198 & 411 & 1.787 & 2.194 & 2.293 & 2.797 \\
\hline Japão & 147 & 307 & 1.529 & 1.812 & 1.808 & 1.978 \\
\hline $\begin{array}{l}\text { Mercados emergentes } \\
\text { e outros países } \\
\text { em desenvolvimento }\end{array}$ & 552 & 905 & 1.298 & 2.378 & 3.527 & 4.208 \\
\hline Ásia & 138 & 284 & 493 & 1.125 & 1.626 & 2.116 \\
\hline China & - & 27 & 77 & 255 & 479 & 659 \\
\hline Coréia do Sul & 33 & 59 & 55 & 147 & 195 & 293 \\
\hline Malásia & 12 & 31 & 31 & 81 & 101 & 115 \\
\hline Tailândia & 10 & 20 & 41 & 138 & 116 & 111 \\
\hline América Latina & 267 & 395 & 492 & 819 & 1.247 & 1.310 \\
\hline Argentina & 29 & 54 & 70 & 144 & 236 & 192 \\
\hline Brasil & 90 & 121 & 153 & 241 & 403 & 420 \\
\hline México & 66 & 108 & 134 & 230 & 309 & 362 \\
\hline Outros & 147 & 226 & 313 & 435 & 654 & 782 \\
\hline
\end{tabular}

Fonte: IMF. International Financial Statistics, 2005. 
está em permanente disponibilidade para ser movimentado instantaneamente nos mercados financeiros de todo o mundo, através dos modernos instrumentos existentes nos dias atuais, disponibilizados pela era da comunicação eletrônica.

O FMI, no seu último Relatório de abril de 2005, ao distinguir duas dimensões da globalização, uma "real" (correspondente ao comércio de bens e serviços) e a outra "financeira" (relativa à integração global dos mercados de capitais), assinala que o começo da era contemporânea da globalização "real" tem início na década de 1950, logo após a implementação do Acordo Geral sobre Tarifas e Comércio - GATT. Atribuindo como principais causas da aceleração da globalização "real" a forte queda nos custos globais de transação - incluindo os custos de transporte, de informação e de barreiras alfandegárias -, os analistas do Fundo mostram que a participação do comércio global de bens e serviços no PIB mundial (comércio global definido como a soma das exportações e importações de bens e serviços) aumentou de 20\%, no início da década de 1970, para cerca de 55\%, em 2003 (FMI, 2005: 129).

No que diz respeito à globalização financeira, esta é definida pelo FMI como iniciada, na era contemporânea, na primeira década dos anos 1970, com a desintegração do regime de Bretton Woods (cuja característica principal foi a substituição dos sistemas de taxas de câmbio fixas pelo de taxas flutuantes) e a crescente liberalização dos mercados financeiros, tanto domésticos quanto externos. A aceleração nessa esfera da globalização, que se intensificou no início da década de 1990, teria decorrido principalmente da dramática redução dos custos de transação e da disseminação de informações (custos de informação, sobretudo telefônicos, e da operação de satélites) e da diminuição de barreiras regulatórias com relação às transações financeiras internacionais (FMI, op. cit.: 110-111).

Ocorreu, por outro lado, e principalmente a partir do início da década de 1990, um crescimento notável das oportunidades de diversificação geográfica dos investimentos internacionais. A tabela 3 - que mostra a expansão e a distribuição, por grandes regiões e países selecionados, dos ativos e passivos estrangeiros no período de 1980 a 2003 — revela a grande concentração ainda desses fluxos de investimentos entre os próprios países industrializados, mas também uma crescente e expressiva participação dos países em 
desenvolvimento, especialmente dos chamados “emergentes”. Essa tabela mostra, por exemplo, valores quase inexpressivos de investimentos externos nas nações em desenvolvimento no início da década de 1980 (US\$ 114 bilhões de ativos), evoluindo tais valores para quase dois trilhões de dólares em 2003, enquanto as cifras correspondentes de passivos se elevavam de pouco mais de US\$ 550 bilhões para mais de US\$ 4,2 trilhões.

A mesma tabela (e os gráficos 7 e 8) mostra, ainda, o principal destino desses investimentos entre os países não industrializados. A China, a Coréia, a Malásia e a Tailândia, na Ásia, e o Brasil, o México e a Argentina, na América Latina, destacam-se amplamente como os principais destinatários dos investimentos externos (diretos e de portfolio). As presenças da China e do Brasil chamam especial atenção. No caso da China, este país, de uma participação quase inexistente, em 1980, como destino internacional de investimentos externos, expande espetacularmente o seu envolvimento como nação receptora de capitais externos, com cifras evoluindo de tão-somente US\$ 18 e US\$ 27 bilhões de ativos e passivos, respectivamente, em 1985, para valores de US\$ 273 bilhões e US\$ 659, em 2003 — tornando-se, de longe, o país com o maior volume de ativos e passivos oficialmente registrados de capitais externos dentre todos os países em desenvolvimento. O Brasil, por sua vez, embora revelando um crescimento menos espetacular do que a China como tomador de recursos externos, alcança, em 2003 (o último nas estatísticas do FMI), o terceiro lugar dentre as nações não industrializadas, perdendo apenas para a própria China e a Coréia, no que se refere a ativos registrados. Esses ativos passaram de US\$ 10 bilhões, em 1980, saltando para US\$ 51 bilhões, em 1995, alcançando a cifra de US\$ 96 bilhões, em 2003 valores inferiores apenas aos US\$ 273 bilhões da China e aos US\$ 127 bilhões da Coréia. Quando se considera a posição externa dos passivos, porém, o Brasil assume o segundo lugar - ficando atrás apenas da China, e bem mais próximo a esse país asiático, com cifras respectivas de US\$ 659 bilhões para a China, como visto, e de US\$ 420 bilhões para o Brasil.

Examinando-se, agora, os impactos da globalização, tanto na sua dimensão real quanto na financeira, as análises mais recentes mostram a ocorrência, principalmente nas últimas três décadas, de grandes mudanças nas magnitudes, na composição e na direção dos fluxos do comércio e dos investimentos. 
Gráfico 7: Evolução do ativo externo bruto - 1985-1995-2003 Em US\$ bilhões

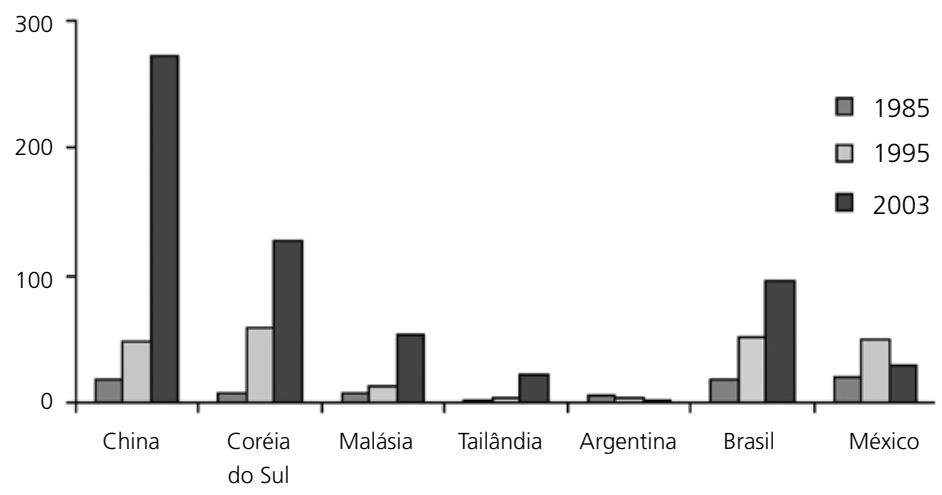

Gráfico 8: Evolução do passivo externo bruto - 1985-1995-2003 Em us\$ bilhões

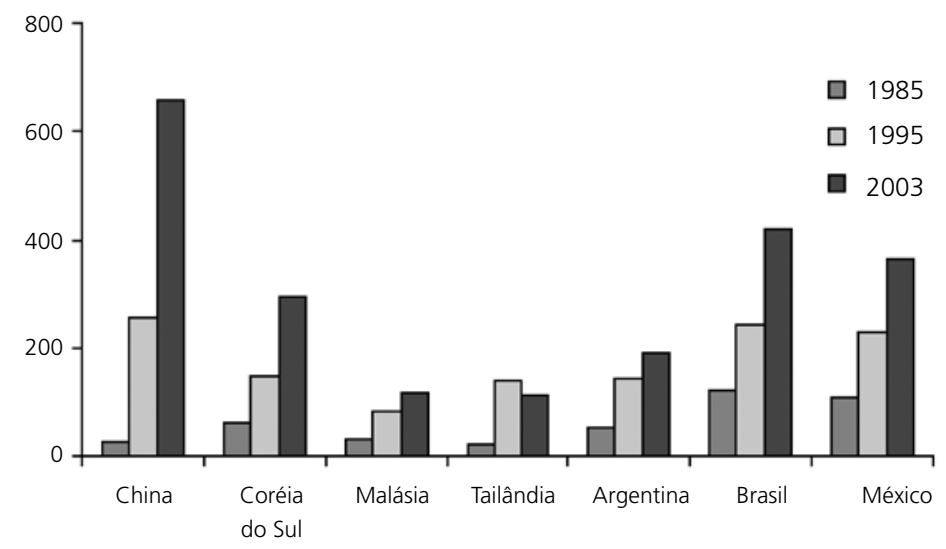

Fonte dos dados básicos: IMF. International Financial Statistics, 2005.

Com relação às mudanças nas magnitudes e na composição do comércio, constata-se, nos dias atuais, o fortalecimento de uma tendência já observada há várias décadas: a de que a maior parte dos fluxos mundiais de bens industrializados é constituída por uma grande variedade de produtos similares, refletindo tanto uma maior preferência dos consumidores por produtos diferenciados como as estratégias empresariais adotadas por uma grande quantidade de firmas de diferentes países em várias partes do planeta, na esfera industrial. Essa mudança na natureza do comércio (a predominância do chamado comércio intra-indústria, em contraposição ao interin- 
dústria) tem trazido como implicação uma notável expansão dos fluxos globais de mercadorias, tornando tanto as nações industrializadas quanto as em desenvolvimento grandes exportadoras e importadoras de bens manufaturados.

Outra implicação importante da globalização é a disseminação das práticas do out-sourcing (ou global-sourcing), que consiste na busca de fornecedores externos de insumos, partes e componentes, muitos dos quais eram antes produzidos dentro da própria empresa. Essas mudanças, baseadas em um novo conceito de especialização flexível, surgiram do hoje quase desaparecido regime fordista de produção em massa e verticalizado, que foi progressivamente substituído por outro, mais centrado em processos de produção flexível, no sentido de que tanto o capital quanto a mão-de-obra devem se prestar a propósitos cada vez mais gerais e universais, e ser capazes de operar dentro de contextos que exigem rápidas alterações voltadas para a criação de novos produtos, novos processos e novos métodos de organização. Essas mudanças foram, portanto, resultado da intensificação da competição internacional, das freqüentes alterações nos padrões da demanda na direção de produtos mais diferenciados e de um crescente desejo dos consumidores por produtos mais variados e de melhor qualidade. Esses fatores, por sua vez, levaram a profundas reestruturações nos sistemas produtivos e de gestão da mão-de-obra, para torná-los mais capazes de atender ao encurtamento do ciclo de vida dos produtos e de responder aos novos desafios do mercado, através de aceleradas taxas de inovação e de avanços no progresso técnico (Galvão, 2000 e 2006).

Essa nova ordem industrial, que afetou inicialmente as grandes corporações transnacionais e depois outras empresas de tamanhos menores, caracterizou-se, assim, por uma grande flexibilidade organizacional, tanto em nível de processos internos de produção - mediante o uso de tecnologias que possibilitam rápidas mudanças no perfil da oferta de bens produzidos - quanto em nível locacional, consubstanciada na tendência da localização de diversas operações da firma transnacional em diferentes partes do mundo. Com relação a este último aspecto, parece ter ficado definitivamente consagrado que a noção de que nem todos os produtos devem ser produzidos em um único país (o princípio das vantagens comparativas) deve vir acompanhada por uma outra: a de que nem todos os produtos de uma in- 
dústria devem ser fabricados em uma única planta. O que significa dizer, em síntese, que nenhum país ou região pode ser competitivo em todos os produtos, nem nenhuma firma pode ser competitiva em todos os locais (Porter, 1993: 15). O resultado desse novo "paradigma tecnológico" foi a crescente fragmentação na produção de bens manufaturados e a distribuição da produção em múltiplas localizações (FMI, 2005: 130), fazendo com que a firma moderna possa se beneficiar da redução de seus custos globais, através tanto da localização de segmentos diferentes de suas operações no local mais apropriado, quanto da compra de componentes, peças e insumos de outras firmas em todo o mundo, buscando aumentar a sua competitividade.

Todas essas alterações nos cenários globais provocaram outro impacto de grande relevância: a globalização, real e financeira, vem mudando, de forma profunda, os padrões geográficos da localização industrial, dos investimentos e do comércio, propiciando a emergência de uma nova configuração espacial da economia mundial. Nessa nova configuração, ainda em processo de consolidação, observa-se uma melhor distribuição da produção industrial, dos investimentos e dos fluxos do comércio entre os continentes e as grandes regiões. Confrontando-se o ano 1980 e os primeiros anos do novo milênio, constata-se, por exemplo, a redução da importância relativa da economia dos Estados Unidos, a ascensão da Europa e do Japão e o aumento da participação de uma série relativamente numerosa de países de economias emergentes, principalmente da Ásia, mas também de algumas nações de outras regiões.

A partir da década de 1960, muitos países do mundo não industrializado adotaram estratégias de desenvolvimento industrial — ora centradas na substituição de importações, ora na expansão de exportações. Em ambos os casos, tais iniciativas desenvolvimentistas contaram com o firme apoio dos governos, e, embora o grau de sucesso dessas estratégias de industrialização tenha diferido largamente, elas permitiram que um número significativo de novas nações, em vários continentes, ingressasse no novo milênio abrigando uma base industrial de expressiva e crescente magnitude.

Países que, até o início da década de 1960, dependiam ainda quase inteiramente da agricultura emergiram como nações exportadoras de produtos industrializados, não somente dos chamados setores tradicionais, mas 
também com presença expressiva e crescente no comércio de bens com demanda altamente dinâmica e incorporando as tecnologias mais sofisticadas. $^{7}$

Países como Coréia, Taiwan, Cingapura, Tailândia, Malásia, China, Índia, México e Brasil - somente para citar alguns - são hoje grandes exportadores de produtos industrializados, com presença expressiva nos mercados internacionais da indústria de tecnologia da informação e de comunicações, como semicondutores, câmeras digitais, aparelhos celulares, computadores e periféricos, softwares e produtos eletroeletrônicos em geral, e de equipamentos da indústria aeronáutica. Muito expressivo a registrar é o fato de que, em 2002, os países em desenvolvimento já eram responsáveis por mais de metade de todo o comércio mundial de produtos do setor da indústria da informação e de telecomunicações - o setor conhecido como ITC. Com efeito, segundo dados da OMC, a participação dos países em desenvolvimento nas exportações mundiais do setor alcançou, no ano mencionado, a cifra de 52\%. Considerando-se que os anos 2003, 2004 e 2005 registraram picos históricos de exportações pelas nações em desenvolvimento de produtos do setor da informação e telecomunicações (principalmente as do Sul e Leste da Ásia), esses valores devem estar próximos ou talvez já tenham superado os 55\% das exportações mundiais, em 2005 (cf. WTO News, março de 2005; e WTO, 2005).

Destaque especial merecem a China e os quatro países recém-industrializados do Sudeste asiático. A China, por exemplo, tornou-se, em 2004, o terceiro maior exportador do mundo, superando inclusive o Japão, com exportações e importações totais de US\$ 593 bilhões e US $\$ 561$ bilhões, respectivamente, com ampla predominância de produtos manufaturados, liderados por produtos da indústria da informação e de telecomunicações. No que diz respeito aos quatro países do Sudeste asiático (Coréia, Taiwan, Cingapura e Hong Kong), as suas exportações e importações somaram respectivamente US\$ 637 bilhões e US\$ 586 bilhões, todos de igual modo com presença marcante nos mercados dinâmicos da nova indústria de equipamentos eletrônicos. Todos esses cinco países, mais o México e a Malásia, se situam entre os 20 maiores exportadores mundiais, com uma participação expressiva e crescente no valor total das exportações globais (OMC/WTO, 2005: 21). 


\section{OS CASOS ESPECIAIS DA ÍNDIA E DA CHINA}

Esta seção faz uma breve descrição dos casos especiais de crescimento de dois países asiáticos: a China, no Leste, e a Índia, no Sul.

Ambos os países, os mais populosos do mundo, cada um com 1 bilhão ou mais de habitantes, abrigam o maior número de pessoas que sobrevivem com menos de US\$ 1 por dia, e apresentam os mais severos problemas de desigualdades sociais, degradação ambiental, carências educacionais e de saúde pública e um extremo quadro de pobreza rural e urbana.

Esses dois países, todavia, vêm registrando, nas duas últimas décadas, notáveis progressos na área econômica, exibindo elevadas taxas de crescimento de seus PIBs e impressionante expansão de suas exportações.

As três tabelas adiante mostram, sob as perspectivas do crescimento do PIB e do comércio exterior, o desempenho comparativo de um conjunto de regiões e países selecionados.

Tabela 4: Crescimento do PIB real, segundo países e áreas selecionadas, 1987-2004 (em \%)

\begin{tabular}{|c|c|c|c|c|c|c|c|c|c|}
\hline Discriminação & 1987-1996 & 1997 & 1998 & 1999 & 2000 & 2001 & 2002 & 2003 & 2004 \\
\hline Mundo & 3,3 & 4,2 & 2,8 & 3,7 & 4,6 & 2,5 & 3,0 & 4,0 & 5,1 \\
\hline $\begin{array}{l}\text { Economias } \\
\text { desenvolvidas }\end{array}$ & 3,0 & 3,4 & 2,6 & 3,5 & 3,8 & 1,2 & 1,6 & 2,0 & 3,4 \\
\hline Estados Unidos & 2,9 & 4,5 & 4,2 & 4,4 & 3,7 & 0,8 & 1,9 & 3,0 & 4,4 \\
\hline Zona do Euro & & 2,4 & 2,8 & 2,8 & 3,6 & 1,6 & 0,9 & 0,5 & 2,0 \\
\hline Reino Unido & 2,1 & 3,1 & 2,8 & 2,5 & 3,6 & 1,6 & 1,3 & 1,7 & 2,6 \\
\hline Japão & 3,2 & 1,7 & $-1,1$ & - & 2,4 & 0,2 & $-0,3$ & 1,4 & 2,6 \\
\hline África & 2,2 & 3,2 & 3,0 & 2,8 & 3,2 & 4,0 & 3,6 & 4,6 & 5,1 \\
\hline $\begin{array}{l}\text { Europa Central } \\
\text { e do Leste }\end{array}$ & 0,9 & 4,2 & 2,8 & 0,4 & 4,9 & 0,2 & 4,4 & 4,6 & 6,1 \\
\hline $\begin{array}{l}\text { Ásia (países em } \\
\text { desenvolvimento) }\end{array}$ & 7,8 & 6,5 & 4,1 & 6,2 & 6,5 & 5,8 & 6,5 & 8,1 & 8,2 \\
\hline China & 10,0 & 8,8 & 7,8 & 7,1 & 8,0 & 7,5 & 8,3 & 9,3 & 9,5 \\
\hline Índia & 5,9 & 5,2 & 5,6 & 6,9 & 4,7 & 4,8 & 4,4 & 7,5 & 0,3 \\
\hline Os demais & 6,4 & 3,9 & $-4,5$ & 3,8 & 5,4 & 3,2 & 4,7 & 5,7 & 5,9 \\
\hline Oriente Médio & 3,4 & 4,8 & 4,0 & 2,1 & 5,4 & 3,3 & 4,1 & 5,8 & 5,5 \\
\hline América Latina e Caribe & 2,8 & 5,2 & 2,3 & 0,4 & 3,9 & 0,5 & $-0,1$ & 2,2 & 5,7 \\
\hline Brasil & 2,1 & 3,3 & 0,1 & 0,8 & 4,4 & 1,3 & 1,9 & 0,5 & 5,2 \\
\hline México & 2,5 & 6,8 & 5,0 & 3,6 & 6,6 & - & 0,6 & 1,6 & 4,4 \\
\hline Argentina & 2,6 & 8,1 & 3,8 & $-3,4$ & $-0,8$ & $-4,4$ & $-10,9$ & 8,8 & 9,0 \\
\hline
\end{tabular}

Fonte: IMF. World Economic Outlook, 2005. Globalization and External Imbalances. Washington: IMF, 2005.

Obs.: Na tabela original do Relatório do FMI não consta a informação do crescimento do PIB para o México em 2001. 
Os dados da tabela 4, que mostra o crescimento do PIB real segundo principais áreas e países selecionados, destacam claramente a China e a Índia como os dois países que melhor desempenho registraram no período de 1987 a 2004. Vale assinalar, porém, que o take-off dessas duas economias ocorreu pouco antes do início da série aqui apresentada — o da China quase imediatamente após a adoção de seu programa de reforma econômica do final de 1978, e o da Índia a partir da segunda metade da década de 1980.

As informações constantes dessa tabela, coletadas pelo Fundo Monetário Internacional e publicadas em seu Relatório Anual de 2005, mostram um firme e robusto crescimento do PIB real na Índia, de 5,9\% ao ano, ao longo de um período de 10 anos (1987 a 1996), e um crescimento que se manteve elevado, com pequenas oscilações, em torno de $4,5 \%$ a $7,5 \%$, durante todo o restante dos anos 1990 e início do novo milênio. Segundo informações adicionais fornecidas por relatório da Secretaria Geral da ONU, a renda per capita indiana cresceu, na última década, a uma taxa de cerca de $4 \%$ ao ano, principalmente em decorrência de um firme crescimento da agricultura, do setor de serviços e das exportações de alguns produtos manufaturados (ONU, 2005: 163).

Vale notar que essas taxas são bastante expressivas, por contrastarem com as de muitos anos de letargia da economia indiana, principalmente decorrentes do rápido esgotamento de estratégias de introversão do crescimento nacional, baseadas em industrialização por via de substituição de importações, e que foram largamente adotadas após a Segunda Grande Guerra, em seguida à obtenção da independência do país do regime colonial britânico.

A tabela 5, cujos dados foram extraídos do Relatório Anual da OMC de 2005, apresenta outra dimensão do crescimento indiano. Essa tabela mostra a Índia como uma economia muito fechada, mas que começa a se inserir rapidamente na economia mundial. Depois de apresentar um crescimento anual de suas exportações e importações de $7 \%$ e $8 \%$, respectivamente, no período de 1995 a 2000, o comércio exterior indiano revela expressivo dinamismo no triênio 2002-2004, com as exportações crescendo a taxas de 14\%, $16 \%$ e $27 \%$ e as importações ainda mais, ao registrarem expansão de 12, 26 e $34 \%$, em cada um dos anos do triênio considerado. 
Tabela 5: Comércio mundial de mercadorias por região e países selecionados, 2004 Valores em us\$ bilhões

\begin{tabular}{|c|c|c|c|c|c|c|c|c|c|c|c|c|}
\hline \multirow[b]{3}{*}{ Discriminação } & \multirow[b]{3}{*}{ Valor } & \multicolumn{5}{|c|}{ Exportações } & \multicolumn{5}{|c|}{ Importações } & \\
\hline & & & Crescir & ment & o anu & & & Cre & scimen & to ans & & \\
\hline & & & & & & & Valor & & & & & \\
\hline & 2004 & 1995-200 & 002001 & 2002 & 2003 & 2004 & 2004 & $1995-200$ & 02001 & 2002 & 2003 & 2004 \\
\hline Mundo & 8.880 & 5 & -4 & 5 & 17 & 21 & 9.215 & 5 & -4 & 4 & 16 & 21 \\
\hline América do Norte & 1.330 & 7 & -6 & -4 & 5 & 14 & 2.010 & 11 & -6 & 2 & 7 & 16 \\
\hline Estados Unidos & 819 & 6 & -6 & -5 & 4 & 13 & 1.526 & 10 & -6 & 2 & 8 & 17 \\
\hline Canadá & 322 & 8 & -6 & -3 & 8 & 18 & 276 & 8 & -7 & 0 & 8 & 13 \\
\hline México & 189 & 16 & -5 & 1 & 3 & 14 & 206 & 19 & -4 & 0 & 1 & 16 \\
\hline América Central e do Sul ${ }^{1}$ & 272 & 5 & -3 & 0 & 13 & 28 & 238 & 3 & -1 & -13 & 5 & 27 \\
\hline Brasil & 96 & 3 & 6 & 4 & 21 & 32 & 66 & 2 & 0 & -15 & 2 & 30 \\
\hline Demais Países² & 175 & 6 & -7 & -1 & 9 & 26 & 172 & 4 & -1 & -12 & 6 & 25 \\
\hline Europa & 4.024 & 2 & 1 & 7 & 19 & 19 & 4.133 & 4 & -2 & 5 & 20 & 20 \\
\hline União Européia (25) & 3.708 & 2 & 1 & 7 & 19 & 19 & 3.784 & 4 & -1 & 5 & 20 & 19 \\
\hline Alemanha & 915 & 1 & 4 & 8 & 22 & 22 & 717 & 1 & -2 & 1 & 23 & 19 \\
\hline França & 451 & 2 & -1 & 3 & 18 & 15 & 464 & 3 & -3 & 0 & 21 & 16 \\
\hline Reino Unido & 346 & 4 & -4 & 3 & 9 & 13 & 462 & 5 & -3 & 4 & 13 & 18 \\
\hline Itália & 346 & 1 & 2 & 4 & 18 & 16 & 349 & 3 & -1 & 5 & 20 & 17 \\
\hline Demais Países & 204 & 3 & 0 & 4 & 14 & 19 & 165 & 1 & -1 & 2 & 15 & 18 \\
\hline Suíça & 118 & 0 & 1 & 7 & 15 & 18 & 111 & 1 & 1 & -1 & 15 & 16 \\
\hline Sudeste Europeu & 112 & 5 & 10 & 15 & 29 & 32 & 183 & 8 & -8 & 20 & 32 & 36 \\
\hline C.E.I. & 263 & 5 & 0 & 5 & 27 & 35 & 171 & -3 & 16 & 9 & 27 & 31 \\
\hline Rússia & 183 & 5 & 2 & 4 & 27 & 35 & 95 & 6 & 20 & 12 & 23 & 28 \\
\hline África & 228 & 6 & -6 & 3 & 23 & 31 & 207 & 0 & 4 & 1 & 22 & 25 \\
\hline África do Sul & 46 & 1 & -2 & 2 & 23 & 26 & 55 & -1 & -5 & 4 & 40 & 34 \\
\hline Demais Países & 183 & 7 & -7 & 3 & 23 & 32 & 152 & 1 & 6 & 0 & 16 & 22 \\
\hline Export. petróleo 3 & 113 & 12 & -13 & 1 & 27 & 41 & 52 & 0 & 20 & -5 & 21 & 32 \\
\hline Não export. petróleo & 69 & 0 & 2 & 7 & 18 & 19 & 100 & 1 & 1 & 2 & 14 & 18 \\
\hline Oriente Médio & 379 & 12 & -11 & 5 & 21 & 26 & 243 & 4 & 6 & 4 & 13 & 23 \\
\hline Ásia & 2.385 & 5 & -9 & 8 & 18 & 25 & 2.214 & 3 & -7 & 6 & 19 & 27 \\
\hline Japão & 565 & 2 & -16 & 3 & 13 & 20 & 455 & 2 & -8 & -3 & 14 & 19 \\
\hline China & 593 & 11 & 7 & 22 & 35 & 35 & 561 & 11 & 8 & 21 & 40 & 36 \\
\hline Tigres Asiáticos & 637 & 5 & -14 & 5 & 15 & 26 & 586 & 2 & -16 & 3 & 13 & 28 \\
\hline Índia & 73 & 7 & 2 & 14 & 16 & 27 & 95 & 8 & -2 & 12 & 26 & 34 \\
\hline Mercosul & 135 & 4 & 4 & 1 & 19 & 28 & 94 & 2 & -6 & -26 & 10 & 37 \\
\hline Asean & 550 & 6 & -10 & 5 & 12 & 20 & 491 & 1 & -8 & 4 & 10 & 26 \\
\hline Novos memb. da U.E. & 260 & 8 & 11 & 14 & 29 & 32 & 299 & 9 & 6 & 11 & 26 & 28 \\
\hline Países em desenvolv. & 2.780 & 8 & -7 & 7 & 18 & 26 & 2.523 & 5 & -4 & 4 & 16 & 27 \\
\hline Ásia em desenvolv. & 1.712 & 7 & -7 & 10 & 20 & 27 & 1.679 & 4 & -7 & 9 & 21 & 30 \\
\hline
\end{tabular}

Fonte: World Trade Report, 2005. Genebra: WTO, 2005, p. 19.

Obs.: 1. Inclui o Caribe. 2. Argélia, Guiné, Gabão, Nigéria e Sudão. 3. Taiwan, Cingapura, Hong-Kong e Coréia do Sul. 
Assim, ao exibir um total exportado, em 2004, da ordem de US\$ 73 bilhões e de US\$ 95 bilhões em importações, a Índia passa a aparecer entre as principais nações exportadoras e importadoras do mundo, começando a seguir os passos de seus outros vizinhos asiáticos.

Um outro aspecto da economia indiana merece destaque especial. Embora a maioria de suas exportações ainda seja de produtos de baixo conteúdo tecnológico (commodities e manufaturas intensivas em mão-de-obra pouco qualificada), um segmento particular da indústria da Índia tem tido desempenho notável nos últimos anos e alcançado projeção internacional: o de software e de serviços relacionados à informática. Esse setor foi responsável, em 2004, por US\$ 17 bilhões de exportações, respondendo por quase um quarto das exportações indianas totais e pela geração de cerca de um milhão de empregos (Sachs, 2005).

O caso da China é, porém, muito mais impressionante. Como mostra a tabela 4, já mencionada, esse país registrou um crescimento anual do PIB real de 10\%, no período de 1987 a 1996, mantendo um ritmo médio de expansão acima de $8 \%$ ao ano, desde então. Depois de crescer $9,3 \%$ e 9,5\% nos anos mais recentes, 2003 e 2004, a previsão do FMI é de que ocorra (por conta de algumas pressões inflacionárias e do anúncio de medidas fiscais e monetárias restritivas por parte do governo) uma desaceleração do crescimento do PIB chinês no biênio 2005-2006, para "modestos" 8,5\%, em 2005 (desaceleração que de fato não aconteceu, já que o PIB chinês cresceu 9,5\% nesse ano), e 8\%, em 2006 (a taxa de crescimento do PIB chinês alcançou $10,5 \%$ neste ano) e de que essas taxas se mantenham próximas a esse patamar no restante da primeira década dos 2000 (cf. FMI, 2005: 33). Ainda segundo informes da OMC e das Nações Unidas, o número de pobres na China (definidos como pessoas com ganho de menos de US\$1 por dia) caiu em 200 milhões durante as últimas duas décadas e meia, e a renda per capita desse país evoluiu em mais de seis vezes, também nesse período (cf. WTO News, 2003; e ONU, 2005).

Se o crescimento do PIB chinês tem sido impressionante, a expansão de seu comércio exterior é espetacular, com exportações crescendo de forma sustentada a $14 \%$ ao ano, em média, nas últimas pouco mais de duas décadas - três vezes mais rapidamente do que o comércio mundial no mesmo período. E mesmo considerando que as exportações chinesas há haviam alcançado elevado patamar no início do milênio, essas mesmas exportações se 
expandiram a um ritmo de 22\%, em 2002, e 35\%, em cada um dos anos do biênio 2003-2004 (tabela 5).

Em face do ritmo expressivo de crescimento de suas exportações, a China superou, em 2004, o Japão, passando a ocupar a terceira posição no ranking das nações mais exportadoras de todo o globo (tabelas 5 e 6 e gráficos 9 e 10), alcançando a cifra de US\$ 593 bilhões em exportações, sendo ultrapassada apenas pelos Estados Unidos e pela Alemanha, com valores respectivos de US\$ 819 e US\$ 915 bilhões. Vale notar que, mantido o cresci-

Tabela 6: Principais países exportadores e importadores no comércio mundial de mercadorias, 2004

Valores em US\$ bilhões

\begin{tabular}{|c|c|c|c|c|c|c|c|c|c|}
\hline \multicolumn{2}{|c|}{ Ranking Exportadores } & \multirow{2}{*}{$\begin{array}{l}\text { Valor } \\
914,0\end{array}$} & \multirow{2}{*}{$\begin{array}{c}\% \\
10,0\end{array}$} & \multirow{2}{*}{$\begin{array}{c}\begin{array}{c}\text { Variação no } \\
\text { ano(\%) }\end{array} \\
22\end{array}$} & \multicolumn{2}{|c|}{ Ranking Importadores } & \multirow{2}{*}{$\begin{array}{c}\text { Valor } \\
1.526\end{array}$} & \multirow{2}{*}{$\begin{array}{c}\%) \\
16,1\end{array}$} & \multirow{2}{*}{$\begin{array}{c}\begin{array}{c}\text { Variação } \\
\text { no ano(\%) }\end{array} \\
17\end{array}$} \\
\hline 1 & Alemanha & & & & 1 & Estados Unidos & & & \\
\hline 2 & Estados Unidos & 819,0 & 9,0 & 13 & 2 & Alemanha & 718 & 7,6 & 19 \\
\hline 3 & China & 593,4 & 6,5 & 35 & 3 & China & 561 & 5,9 & 36 \\
\hline 4 & Japão & 565,5 & 6,2 & 20 & 4 & França & 464 & 4,9 & 16 \\
\hline 5 & França & 451,0 & 4,9 & 15 & 5 & Reino Unido & 462 & 4,9 & 18 \\
\hline 6 & Holanda & 358,8 & 3,9 & 21 & 6 & Japão & 455 & 4,8 & 19 \\
\hline 7 & Itália & 346,1 & 3,8 & 16 & 7 & Itália & 349 & 3,7 & 17 \\
\hline 8 & Reino Unido & 345,6 & 3,8 & 13 & 8 & Holanda & 320 & 3,4 & 21 \\
\hline 9 & Canadá & 322,0 & 3,5 & 18 & 9 & Bélgica & 287 & 3,0 & 22 \\
\hline 10 & Bélgica & 308,9 & 3,4 & 21 & 10 & Canadá & 276 & 2,9 & 13 \\
\hline \multirow[t]{3}{*}{11} & Hong Kong, China & 265,7 & 2,9 & 16 & 11 & HongKong, China & 273 & 2,9 & 17 \\
\hline & Exp. Domésticas & 22,6 & 0,2 & 15 & & Importações retidas $^{1}$ & $s^{1} \quad 30$ & 0,3 & 24 \\
\hline & Reexportações & 243,1 & 2,7 & 16 & 12 & Espanha & 250 & 2,6 & 20 \\
\hline 12 & Coréia do Sul & 253,9 & 2,8 & 31 & 13 & Coréia do Sul & 224 & 2,4 & 26 \\
\hline 13 & México & 188,6 & 2,1 & 14 & 14 & México & 206 & 2,2 & 16 \\
\hline 14 & Federação Russa & 183,2 & 2,0 & 35 & 15 & Taiwan & 168 & 1,8 & 32 \\
\hline 15 & Taiwan & 181,4 & 2,0 & 21 & 16 & Cingapura & 164 & 1,7 & 28 \\
\hline \multirow[t]{3}{*}{16} & Cingapura & 179,5 & 2,0 & 25 & & Importações retidas ${ }^{1}$ & $s^{1} \quad 83$ & 0,9 & 30 \\
\hline & Exp. domésticas & 98,5 & 1,1 & 23 & 17 & Áustria & 115 & 1,2 & 16 \\
\hline & Reexportações & 81,0 & 0,9 & 26 & 18 & Suíça & 112 & 1,2 & 16 \\
\hline 17 & Espanha & 179,0 & 2,0 & 15 & 19 & Austrália & 108 & 1,1 & 21 \\
\hline 18 & Malásia & 126,5 & 1,4 & 21 & 20 & Malásia & 105 & 1,1 & 26 \\
\hline 19 & Suécia & 121,0 & 1,3 & 19 & & & & & \\
\hline \multirow[t]{3}{*}{20} & Arábia Saudita & 119,6 & 1,3 & 28 & & & & & \\
\hline & Países selecionados ${ }^{2}$ & $6.823,4$ & 74,8 & - & & Países selecionados ${ }^{2}$ & 7.143 & 75,5 & \\
\hline & Mundo 2 & $9.123,5$ & 100,0 & 21 & & Mundo & 9.458 & 100,0 & \\
\hline
\end{tabular}

Fonte: World Trade Report, 2005. Genebra: WTO, 2005:19.

Obs.: 1) Importações retidas são classificadas como importações menos reexportações.

2) Inclui reexportações e importações de valores significantes. 
Gráfico 9: Participação (\%) dos principais países exportadores no comércio global, 2004

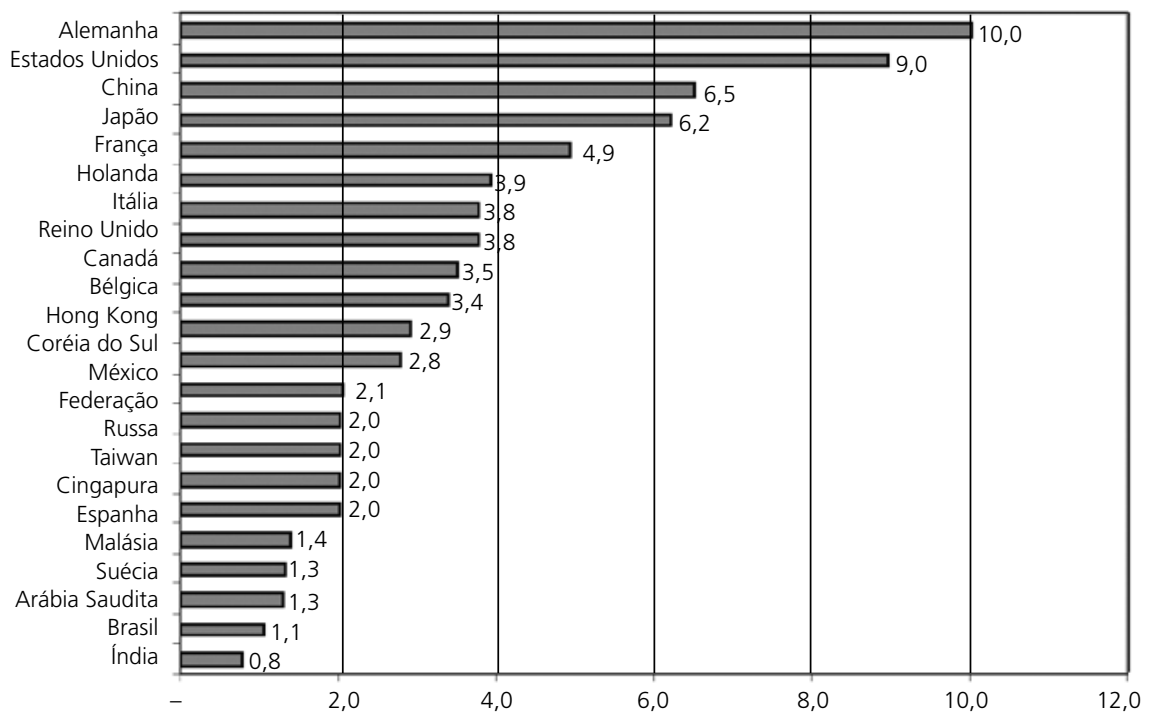

Gráfico 10: Participação (\%) dos principais países importadores no comércio global, 2004

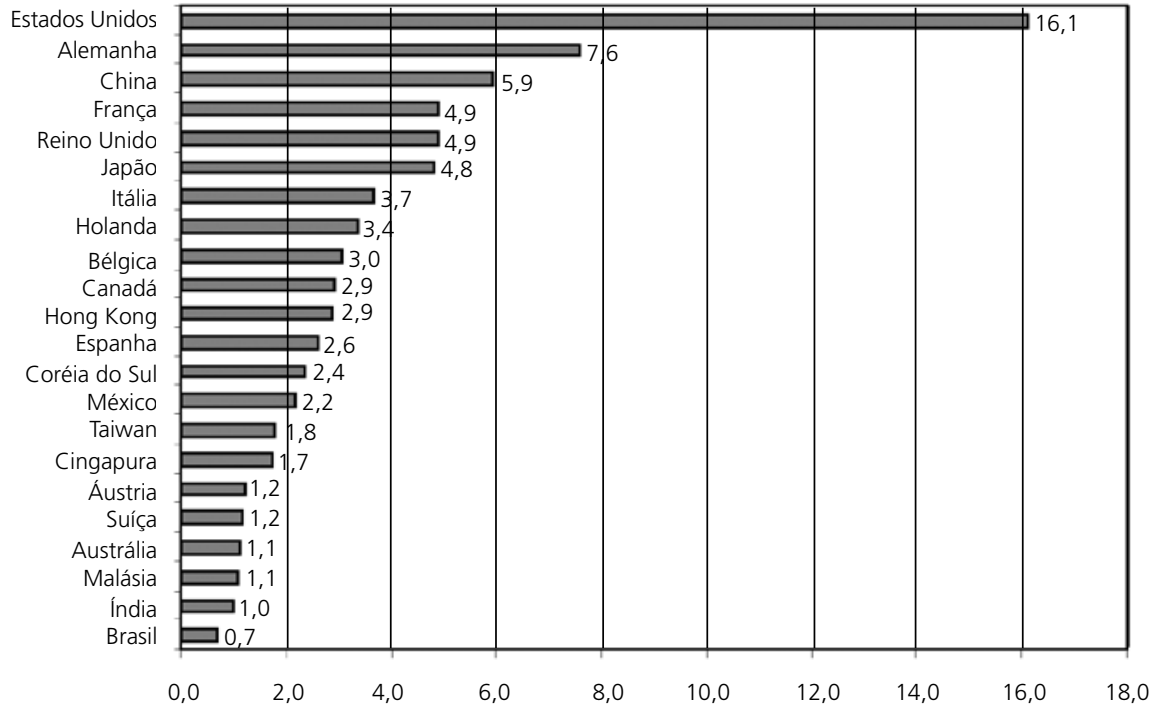

Fonte: World Trade Report, 2005. Genebra: WTO, 2005. Obs.: Brasil e Índia não estão entre os 20 maiores exportadores e importadores e constam do gráfico apenas para ilustração. 
mento das exportações chinesas dos anos mais recentes, a China deverá ultrapassar em não mais que três anos o volume das exportações dos Estados Unidos, e talvez o da própria Alemanha, até o final desta década, fazendo desse país asiático o maior exportador mundial de mercadorias. Por outro lado, por ter acumulado substanciais superavits comerciais com os seus parceiros, além de continuar mantendo ainda mais expressivos excedentes na sua conta de capitais, a China já possui reservas da ordem de US\$ 600 bilhões, com previsão de que tais valores venham a alcançar cifra próxima a US\$ 1 trilhão de reservas cambiais antes do final da presente década.

É importante assinalar que a China também é uma grande economia importadora. Seus US\$ 561 bilhões de importações, em 2004, tornaram-na, também, a terceira nação que mais importou em todo o mundo, e suas importações têm crescido em ritmo muito veloz, sobretudo nos anos mais recentes, e mais rapidamente até que as próprias exportações.

Não é por outra razão que os relatórios mais recentes das organizações internacionais têm assinalado que a China já é um dos motores do crescimento em nível mundial, e que o seu ritmo de expansão (ao lado da economia dos Estados Unidos) já constitui um dos determinantes principais do desempenho das economias de outras regiões do globo (ver os Relatórios Anuais do Banco Mundial, da OMC e do FMI, todos de 2005).

Além das cifras que dizem respeito aos valores do comércio exterior da China, alguns outros aspectos relevantes dessa economia merecem atenção.

Inicialmente, vale registrar que a participação das exportações chinesas no total mundial dobrou, apenas entre 2000 e 2004, evoluindo tal participação de 2,9\% para 5,8\%. Por outro lado, embora o país seja um global trader, mantendo relações comerciais muito intensas com grande número de países, e sobretudo com os seus vizinhos do continente asiático, a penetração dos produtos chineses no mercado norte-americano tem sido sem dúvida notável: no período de 1995 a 2004, além de ter mais que dobrado, chegou a cerca $14 \%$ a participação dos produtos chineses no maior mercado consumidor do mundo (WTO Report, 2005: 8). É interessante assinalar, ainda, que o aumento da penetração da China no mercado americano ocorreu em grande parte às expensas dos países concorrentes do próprio continente asiático, que experimentaram, no período mencionado, uma crescente diminuição da participação das suas exportações de produtos similares no mercado dos Estados Unidos (idem, ibidem). 
Outro aspecto relevante a anotar se refere à composição das exportações chinesas. Como o país é relativamente pobre em recursos naturais e abriga uma vasta população de cerca de 1,3 bilhão de habitantes, a China tem-se especializado predominantemente na produção de bens manufaturados, fato que obviamente tende a se refletir na sua pauta de exportações. Ademais, por ser o maior receptor de capitais estrangeiros, dentre os países em desenvolvimento, e abrigar número expressivo e crescente de filiais de empresas com matrizes nos países industrializados, os chineses dominam grande parte do mercado mundial de produtos da indústria mais tradicional (é o maior exportador de calçados e de bens têxteis, somente estes últimos alcançando, em 2004, a cifra de US\$ 62 bilhões — ver OMC, 2005), mas suas exportações vêm predominantemente se constituindo em produtos voltados para mercados dinâmicos e que apresentam elevado conteúdo tecnológico. A venda de produtos eletrônicos — especialmente câmeras digitais, computadores pessoais, telefones celulares, semicondutores e outros bens da indústria da informação e das telecomunicações - expandiu-se 236\%, somente no período de 2000 a 2004 (FMI, 2005: 63), e, depois de crescer $45 \%$ em 2004, o total das exportações, apenas dessa categoria de produtos, alcançou a impressionante cifra de US\$ 171 bilhões (OMC, 2005: 12). A tendência de expansão desse setor na China deve se acentuar ainda mais nos próximos anos, tendo em vista o fato de um terço de todos os investimentos diretos estrangeiros no país estar concentrado na indústria de semicondutores e produtos correlatos - conforme destaca o World Economic Outlook, de 2005, do FMI (FMI, op. cit.: 63).

Também é de interesse ressaltar o fato de que a China tem, até o momento, disputado não somente mercados de bens manufaturados, mas também o de capitais externos, principalmente com os próprios vizinhos do continente asiático. No que diz respeito especificamente a investimentos diretos estrangeiros (IDEs), um recente estudo realizado pelo Banco da Espanha mostra que, embora tenha havido algum desvio de IDEs da América latina para a China - particularmente no caso do México - , a região como um todo - e especialmente o Brasil, o Chile e a Argentina — não tem sido afetada pelas preferências dos investidores internacionais. $\mathrm{O}$ mesmo estudo assinala, ao contrário, que o crescimento da demanda chinesa por produtos alimentares e matérias-primas tende a estimular a atração de IDEs para a 
América Latina, em geral, e para países abundantes em recursos naturais, em particular, como é o caso do Brasil, e que até a própria China já começa a manifestar interesse em investir diretamente nesses países, para garantir o crescente fluxo de commodities para o mercado chinês. ${ }^{8}$

Um comentário conclusivo sobre a importância do papel da Índia e da China no contexto mundial, e o impacto futuro dessas economias no Brasil, é aqui imperioso.

Inicialmente, parece fazer sentido argumentar que poucas lições podem ser extraídas da experiência de desenvolvimento dessas duas economias que sejam de real interesse para países como o Brasil e outras economias menos desenvolvidas.

Os relatórios mais recentes das diversas organizações internacionais, aqui já citados em várias oportunidades, apresentam a questão chinesa e indiana sob duas perspectivas contrastantes. Em uma primeira, ressaltam, como visto anteriormente, o notável avanço das economias desses dois países, em termos de crescimento de seus PIBs reais, total e per capita, e de sua impressionante performance exportadora. A crescente abertura dessas economias ao capital estrangeiro é louvada, assim como também a nova orientação que tem sido dada às suas estratégias de desenvolvimento, largamente centradas na expansão das exportações e na conquista de mercados externos.

Todavia, os analistas que elaboraram esses mesmos relatórios assinalam, consensualmente, que o desenvolvimento dessas duas economias vem sendo acompanhado, ou vem sendo diretamente responsável, por agudos problemas em outras várias dimensões. Tanto na China quanto na Índia são crescentes as desigualdades sociais e regionais, tem crescido intensamente o ritmo de degradação ambiental, têm sido expandidas as diferenças nas oportunidades de ascensão social entre populações de níveis sociais e educacionais mais baixos, vêm sendo reduzidas ou desmanteladas antigas redes de proteção à saúde pública, bem como elevado severamente o nível de stress de vastos segmentos da população que deixam o interior em direção às cidades.

No caso específico da Índia, embora pesquisas do Banco Mundial e da ONU reconheçam que o rápido crescimento desse país, em anos recentes, tenha reduzido o número total de pobres (de 37,5\% para 26\%, entre 1990 e 2000 , considerando uma linha de pobreza compreendendo pessoas com ga- 
nhos de menos de US\$ 1 por dia), tais pesquisas também assinalam a permanência de elevadas taxas de subnutrição, um enorme contingente de crianças fora da escola, uma piora nos indicadores de saúde e no comportamento de outros índices sociais e econômicos, principalmente entre mulheres, crianças e membros de populações tribais ou de castas consideradas inferiores. A Índia apresenta um elevado e crescente número de população contaminada pelo vírus HIV (4,6 milhões de pessoas) - perdendo apenas para a África do Sul — e a maior incidência do mundo de pessoas infectadas pelo bacilo da tuberculose. Por outro lado, os mesmos estudos ainda revelam serem enormes e crescentes as disparidades de desenvolvimento entre as regiões indianas, sobretudo entre os populosos estados do centro e do norte, em contraste com os das regiões do sul e mais próximos ao litoral desse país (Banco Mundial, 2005b; e ONU, 2005). Vale acrescentar, ainda, que, nas regiões mais prósperas e que têm revelado alto grau de dinamismo industrial, tem-se verificado um aumento da informalidade no mercado de trabalho e uma significativa expansão das chamadas sweat shops, que são sistemas fabris baseados na exploração da mão-de-obra barata, sem direito à previdência social e seguro-saúde e com jornadas de trabalho de 10 e até 12 horas por dia, inclusive para crianças (Galvão, 2000).

$\mathrm{O}$ quadro referente à China apresenta ainda muito maior gravidade. Os processos de desregulamentação que ocorreram nesse país praticamente eliminaram as redes de proteção social que existiam para vastos segmentos da população chinesa, durante a plenitude do regime comunista. Segundo um relatório das Nações Unidas de 2005, o sistema de saúde pública foi quase totalmente desmantelado, colocando tal sistema, de acordo com palavras dos analistas da ONU, sob "severo stress", na medida em que os índices de cobertura de saúde da população rural (ainda mais de 50\% da população chinesa) declinaram de $90 \%$ para menos de $10 \%$, entre o final da década de 1970 e 1998. A conseqüência foi um empobrecimento em massa dessa população residente nas pequenas vilas e cidades do interior, produzindo efeitos catastróficos (ainda segundo termos do relatório) sobre centenas de milhões de pobres agricultores chineses. No que diz respeito ainda à saúde, são assustadores os números relativos à contaminação pelo vírus HIV. Hoje calculado em um milhão de pessoas afetadas, estudos da ONU estimam que tal número poderá alcançar os 10 milhões, por volta de 2010, caso o governo 
não tome providências imediatas para um eficaz controle dessa doença (ONU, 2005: 159).

A degradação ambiental é apontada como outra séria conseqüência do crescimento econômico chinês. Segundo pesquisas citadas pelo mencionado relatório, mais de $90 \%$ das pastagens chinesas já estariam totalmente degradados e mais de 75\% da água dos rios nas áreas urbanas estão inadequados até para "contato humano". No que se refere à poluição urbana, seis das 10 cidades mais poluídas do globo estão localizadas na China.

$\mathrm{O}$ rápido crescimento da China também tem provocado severos desequilíbrios regionais, sobretudo entre as províncias mais urbanizadas do litoral e vastas áreas do interior do país, que apresentam graves carências em infra-estrutura econômica e social. As desigualdades sociais nos centros urbanos mais industrializados também são crescentes, abrigando as grandes cidades mais de 175 milhões de habitantes vivendo em favelas ou cortiços sem saneamento e água tratada (ONU, op. cit.: 163).

Embora todos os estudos das organizações aqui mencionadas (FMI, Banco Mundial, OMC e ONU) assinalem que o crescimento chinês deverá continuar ocorrendo a taxas elevadas ainda nos próximos anos, tais estudos também deixam implícita a ressalva de que, se continuar nos mesmos padrões, dificilmente o desenvolvimento da China ocorrerá de forma sustentável, provocando ainda maiores impactos negativos sobre as condições de habitabilidade não somente para a população desse país, mas também talvez para todo o planeta. ${ }^{9}$

\section{CONCLUSÃO}

Nas últimas três a quatro décadas eventos importantes ocorridos na esfera mundial repercutiram grandemente nas economias dos países da América Latina e, particularmente, na brasileira.

A extraordinária elevação dos preços do petróleo na década de 1970, a escalada das taxas de juros nos mercados financeiros internacionais e a forte recessão que se seguiu a esses dois eventos nas economias industrializadas marcaram profundamente os cenários macroeconômicos mundiais.

No Brasil, cuja economia se caracterizava por reduzida inserção nos fluxos do comércio internacional, por forte endividamento externo e expressi- 
vo grau de atraso tecnológico, tais cenários trouxeram dramáticas implicações desfavoráveis. Manifestadas principalmente pela criação de um estado permanente de fragilização da economia nacional, as conseqüências dos eventos mencionados contribuíram para a interrupção de uma trajetória de cerca de 50 anos de relativamente rápido crescimento do PIB brasileiro e para a emergência de novos obstáculos à continuidade do desenvolvimento do país, que perduram até os dias atuais.

Os anos do pós-guerra também presenciaram uma notável intensificação do processo de globalização, nas esferas comercial, financeira e tecnológica, tornando as ligações de cada economia nacional com a economia global muito mais estreitas, e criando novos desafios e oportunidades — desafios que foram enfrentados, e oportunidades que foram aproveitadas, é importante ressaltar, de forma desigual, por diferentes continentes e seus países.

O mundo observou, nas últimas décadas, marcantes tendências de constituição de novas configurações espaciais, que estão rapidamente mudando o equilíbrio das forças econômicas globais e criando uma nova geografia de poder, baseada na industrialização de vastas e distantes áreas da periferia das economias centrais, no espetacular incremento das exportações de produtos com alto conteúdo tecnológico de países dessa periferia e sobretudo na incorporação em seus processos produtivos de níveis crescentes de capital humano e de conhecimentos de avançadas tecnologias.

Alguns países do leste asiático, como Coréia e Taiwan, já romperam com um passado de pobreza e subdesenvolvimento, graças a bem-concebidas estratégias de longo prazo de inserção de suas economias nas correntes do comércio mundial e principalmente em decorrência das avançadas políticas de inserção social de sua população, mediante a universalização do ensino fundamental e, nos presentes dias, até do terceiro grau, e também em conseqüência da adoção de políticas que resultaram em níveis de distribuição da renda que já se comparam aos padrões dos países do chamado Primeiro Mundo. Tais países (que incluem ainda as cidades-estado de Cingapura e Hong Kong) superaram o enorme desafio do crescimento com eqüidade social e equilíbrio ambiental a ponto de já serem listados, nos relatórios mais recentes de organizações internacionais (como o do FMI de 2005), ao lado das outras nações avançadas do mundo industrializado. 
Outros países asiáticos, com destaque para a Índia, a China, a Tailândia e a Malásia, fornecem exemplos de como é possível escapar da armadilha das restrições ao crescimento, embora os resultados desse crescimento também tenham vindo acompanhados de muitas lições a evitar. A esse respeito, o caso da China é exemplar, ao mostrar os custos elevados que a grande maioria de sua população está sendo obrigada a pagar, em termos de degradação ambiental, poluição de seus cursos d'água, destruição de redes de proteção social e aprofundamento das desigualdades regionais e sociais.

O Brasil, ao manter a sua economia fechada até o final da década de 1980 e ter negligenciado, até os dias atuais, as dimensões sociais de seu desenvolvimento, principalmente no que diz respeito à educação, perdeu, nas últimas décadas, muitas oportunidades que o mundo em transformação oferecia ao país, que passou a testemunhar, progressivamente, a diminuição da sua importância no contexto mundial.

A eliminação da enorme defasagem tecnológica de sua economia, mesmo quando comparada à de outras nações em desenvolvimento, uma drástica mudança na prioridade conferida à educação e à saúde e a superação da incapacidade de o país se libertar das amarras que vêm impedindo, por várias décadas, o seu crescimento constituem os grandes desafios a enfrentar pela sociedade brasileira nesta próxima geração.

\section{NOTAS}

1. Entre os principais eventos localizados destacam-se as duas crises do México (1986 e 1994), a do Sudeste da Ásia (1996) e as da Rússia, do Japão, da Argentina e do Brasil, ao longo da década de 1990. O desmantelamento das economias do bloco comunista na Europa, ocorrido no período 1989-1991, também pode ser mencionado como um evento localizado com grandes repercussões internacionais.

2. É importante assinalar que a tendência do gráfico 6 não deve ser confundida com o conhecido fenômeno da deterioração dos preços dos bens primários (grosso modo, uma comparação entre preços de commodities exportadas e preços de industrializados importados). A tendência verificada pode estar refletindo os grandes avanços tecnológicos ocorridos na área agrícola e no agribusiness, nas últimas décadas, especialmente nos países em desenvolvimento, e que seria responsável pela queda de custos e, portanto, de preços, no mercado internacional. Além do mais, é muito provável que a mesma tendência de longo prazo de declínio dos preços reais tenha ocorrido também para os bens industrializados, em virtude dos igualmente (ou ainda maiores) avanços tecnológicos verificados em escala mundial no setor industrial. A implicação principal a ser extraída do gráfico 6 não é a de que os países em desenvolvimento devam abandonar a produção 
de bens primários - já que são estes nos quais residem as suas maiores vantagens comparativas, além de continuarem sendo fonte crucial de geração de renda, emprego e de receitas em moeda estrangeira —, mas a de que, como sugerido acima, a diversificação da pauta de exportações, o esforço para uma crescente agregação de valor às commodities e uma eficiente política de industrialização constituem a combinação mais eficaz para enfrentar os problemas que decorrem da dependência de um pequeno número de bens primários exportados.

3. Além do World Economic Outlook, do FMI (FMI, 2005), as informações sobre o desempenho da economia mundial foram confrontadas com as do World Trade Report, da OMC/WTO (WTO, 2005) e do Global Economic Prospects, do Banco Mundial, de 2005 (World Bank, 2005a).

4. O Banco Mundial, no seu Global Economic Prospects, de 2005, faz uma previsão de crescimento do PIB per capita mundial, para o período de 2006 a 2015, de 3,5\% ao ano um desempenho, segundo o referido estudo, correspondente a mais que o dobro da taxa observada na década de 1990. O staff do Banco, todavia, baseia as suas projeções na expectativa de que os preços do petróleo cairiam em 2005 e em 2006, e se manteriam baixos nos anos seguintes, embora admita a possibilidade de que o contrário venha a ocorrer. Neste caso, o estudo do Banco deixa claro que as previsões de crescimento serão menos favoráveis (World Bank, 2005a: 2 e 3).

5. Segundo o Relatório Global Economic Prospects, de 2005, do Banco Mundial, dos 45 países da África Subsaariana, um quarto foi vitimado por pelo menos uma guerra civil no período entre 1970 e 2000 (World Bank: 2005a: 26).

6. Durante toda a primeira metade do século $\mathrm{XX}$, o comércio internacional se expandiu lentamente e concentrou-se entre os países industrializados, constituindo esses dois fenômenos, é bom lembrar, justificativas importantes para a adoção de estratégias de introversão do crescimento da parte de muitas economias menos desenvolvidas, após a grande crise dos anos 1930 (cf. Nurkse, 1959; e Prebisch, 1959). A segunda metade do século mencionado presenciou uma forte aceleração dos fluxos de comércio, dessa vez comandada pelas nações do Terceiro Mundo (cf. Bhagwati, 1988), sobretudo durante as décadas de 1980 e 1990 e os primeiros anos do novo milênio, elevando significativamente a participação desses países nas exportações mundiais. Segundo informações da Organização Mundial do Comércio, em 2004 a participação dos países em desenvolvimento nos fluxos mundiais de mercadorias alcançou quase um terço, constituindo a maior cifra registrada por esses países desde 1950 (ver o World Trade Report, OMC/WTO, 2005).

7. A emergência da "nova ordem industrial" e o surgimento de uma nova era tecnológica vieram acompanhados, sobretudo na década de 1980, de uma crescente onda de pessimismo com relação às perspectivas dos países e regiões menos desenvolvidos, sob o argumento de que a "sociedade do futuro" estaria baseada na informação e no conhecimento. Assim, argüia-se que a "nova indústria" se instalaria apenas nas regiões e países já industrializados, que reuniriam os recursos do capital, do conhecimento e das novas tecnologias, além do seu vasto pool de mão-de-obra qualificada. Embora esse argumen- 
to contenha forte elemento de verdade, e não restem dúvidas de que a "modernidade não está aberta a todos [indivíduos, países e regiões] de igual maneira e simultaneamente" (Gatto, 1990: 39), vale lembrar que, na ordem industrial em gestação, muitas das novas vantagens comparativas se assentam sobre fatores socialmente construídos, no sentido de que resultam de decisões de política econômica, científica e tecnológica de agentes públicos e privados. Além do mais, não se deve desprezar o fato de que ainda haverá muito espaço para o desenvolvimento de indústrias dependentes de recursos naturais ou de mão-de-obra barata — desde as mais tradicionais, como a de calçados, têxtil e de processamento de alimentos, até as mais intensivas em capital, como a química, a siderúrgica, a de celulose e papel e a de material elétrico e eletrônico de consumo. Nesse contexto, mesmo sem se tornarem centros de geração de tecnologia, muitos países menos desenvolvidos poderão abrigar número expressivo de iniciativas industriais em ramos menos sofisticados da "sociedade pós-industrial". Por fim, leve-se ainda em conta que, mesmo concentrando-se nos países industrializados, nem toda a indústria de alta tecnologia deverá necessariamente ficar localizada nos países de economia central. A experiência das economias do Leste e Sul asiáticos (Coréia, Taiwan, China etc.) e alguns casos por enquanto ainda menos generalizados em outras regiões (inclusive o Brasil) revelam que, com uma boa estratégia de política industrial e o comprometimento dos governos e da iniciativa privada com a formação de capital humano, uma parte expressiva das novas indústrias "pós-fordistas" poderá se localizar e prosperar na "periferia” do mundo desenvolvido.

8. O estudo aqui mencionado, intitulado "Impacto da China nos Investimentos Diretos na América Latina", realizado pela Banco da Espanha, está citado pela revista Valor Econômico Online, em sua edição no 1.316 , de 3/8/2005, obtida no site < www.valoronline.com. br>. (consulta em 4/8/2005).

9. Segundo um cáustico crítico da experiência chinesa, a introdução de uma forma de hipercapitalismo na China teria transformado os trabalhadores chineses em tecnocoolies — uma combinação inusitada de salários baixíssimos e alta tecnologia, com um regime autoritário (Sachs, 2005).

\section{REFERÊNCIAS BIBLIOGRÁFICAS}

BHAGWATI, J. (1988) Protectionism. Cambridge: The MIT Press.

GALVÃO, O. de A. (2000) “Clusters e distritos industriais: estudos de casos em países selecionados e implicações de política”. Revista Planejamento e Políticas Públicas, Brasília, DF: Ipea, n. 21.

- (2006) "Globalização e tendências contemporâneas do comércio internacional: o Brasil e o Nordeste no contexto mundial" (Mimeo, 101 p., Recife, PE).

GATTO, F. (1990) "Câmbio tecnológico neofordista y reorganizacion productive: primeras reflexiones sobre sus implicaciones territoriales”. In: F. Albuquerque et. al. (orgs.), Revolucion tecnologica y reestruturacion productive: impactos e desafios territoriales. Buenos Aires: [s.n.]. 
HOBSBAWM, E. (1995) Age of extremes: the short twentieth century, 1914-1991. Londres: Abacus.

IMF (2005) World Economic Outlook: globalization and external imbalances. Washington: IMF.

NURKSE, R. (1959) Patterns af Trade and Development. Estocolmo: Wicksell Lectures.

PORTER, M. E. (1993) A vantagem competitiva das nações. Rio de Janeiro: Campus.

PREBISCH, R. (1959) “Commercial policies in the underdeveloped countries”. American Economic Review, maio.

SACHS, I. (2005) "China, Índia, Rússia e Brasil: pensando em longo prazo”. Revista Rumos, Brasília, DF: ABPE, maio.

UNO (2005) Milleniun Project. Report to the UN Secretary-General. "Investing in Developing: a practical plan to achieve the millenium development goals". USA.

VALOR ECONÔMICO ON-LINE. Ed. n. 1.316. Consulta ao site: www.valoronline.com.br em $4 / 8 / 2005$.

WORLD BANK (2005a) Global Economic Prospects: trade, regionalism and development. Washington: The World Bank.

_ (2005b) Global Monitoring Report 2005. Millennium development goals: from consensus to momentum. Washington: The World Bank.

WORLD TRADE ORGANIZATION (2005) World Trade Report. Exploring the links between trade, standards and the WTO. Genebra.

WTO NEWS (2003) Putting the Doha Development Agenda Back on Track: why it matters to China. Beijing, November.

- (2005) Introductory Remarks by the General Council Chairman. Geneva, July.

- (2005) The WTO After Ten Years: the lessons learned and the challenges ahead. Geneva, March. 